OPEN ACCESS

Check for updates

FAST TRACK

\section{Factors associated with hospital admission and critical illness among 5279 people with coronavirus disease 2019 in New York City: prospective cohort study}

\author{
Christopher M Petrilli, ${ }^{1,2}$ Simon A Jones, ${ }^{3,4}$ Jie Yang, ${ }^{4}$ Harish Rajagopalan, ${ }^{2}$ Luke O'Donnell, ${ }^{1}$ \\ Yelena Chernyak, ${ }^{2}$ Katie A Tobin, ${ }^{2}$ Robert J Cerfolio, ${ }^{2,5}$ Fritz Francois, ${ }^{2,6}$ Leora I Horwitz ${ }^{1,3,4}$
}

\begin{abstract}
${ }^{1}$ Division of General Internal Medicine and Clinical Innovation, Department of Medicine, NYU Grossman School of Medicine, New York, NY, USA

${ }^{2}$ NYU Langone Health, New York, NY, USA

${ }^{3}$ Division of Healthcare Delivery Science, Department of Population Health, NYU Grossman School of Medicine, 227 East 30th Street \#633, New York, NY 10016, USA

${ }^{4}$ Center for Healthcare Innovation and Delivery Science, NYU Langone Health, New York, NY, USA

${ }^{5}$ Department of Cardiothoracic Surgery, NYU Grossman School of Medicine, New York, NY, USA ${ }^{6}$ Division of Gastroenterology, Department of Medicine, NYU Grossman School of Medicine, New York, NY, USA

Correspondence to: L Horwitz leora.horwitz@nyulangone.org (or @leorahorwitzmd on Twitter ORCID 0000-0003-1800-6040)

Additional material is published online only. To view please visit the journal online.

Cite this as: BMJ 2020;369:m1966 http://dx.doi.org/10.1136/bmj.m1966

Accepted: 14 May 2020
\end{abstract}

\section{ABSTRACT}

OBJECTIVE

To describe outcomes of people admitted to hospital with coronavirus disease 2019 (covid-19) in the United States, and the clinical and laboratory characteristics associated with severity of illness.

DESIGN

Prospective cohort study.

SETTING

Single academic medical center in New York City and Long Island.

\section{PARTICIPANTS}

5279 patients with laboratory confirmed severe acute respiratory syndrome coronavirus 2 (SARS-Cov-2) infection between 1 March 2020 and 8 April 2020. The final date of follow up was 5 May 2020.

\section{MAIN OUTCOME MEASURES}

Outcomes were admission to hospital, critical illness (intensive care, mechanical ventilation, discharge to hospice care, or death), and discharge to hospice care or death. Predictors included patient characteristics, medical history, vital signs, and laboratory results. Multivariable logistic regression was conducted to identify risk factors for adverse outcomes, and competing risk survival analysis for mortality.

RESULTS

Of 11544 people tested for SARS-Cov-2, 5566 (48.2\%) were positive. After exclusions, 5279 were included. 2741 of these 5279 (51.9\%) were admitted to hospital, of whom 1904 (69.5\%) were discharged alive without hospice care and 665 (24.3\%) were discharged to hospice care or died. Of 647 (23.6\%)

\section{WHAT IS ALREADY KNOWN ON THIS TOPIC}

Demographics and prevalence of comorbidities in patients with coronavirus disease 2019 (covid-19), particularly those admitted to hospital, have been described in several countries

Early outcomes of people with critical illness have been described but usually include a substantial portion of patients still with incomplete follow-up

It is uncertain which characteristics, comorbidities, and laboratory results are associated with an increase in risk for adverse outcomes

\section{WHAT THIS STUDY ADDS}

In this study of people with covid-19 tested and treated at a health system in New York City the overall mortality rate for patients admitted to hospital was between $24 \%$ and $30 \%$

Age, heart failure, male sex, chronic kidney disease, and obesity were associated with hospital admission and development of critical illness once admitted Hypoxia and increased inflammatory laboratory studies early in hospital admission were important markers for adverse events patients requiring mechanical ventilation, 391 (60.4\%) died and 170 (26.2\%) were extubated or discharged. The strongest risk for hospital admission was associated with age, with an odds ratio of $>2$ for all age groups older than 44 years and 37.9 (95\% confidence interval 26.1 to 56.0 ) for ages 75 years and older. Other risks were heart failure $(4.4,2.6$ to 8.0), male sex (2.8, 2.4 to 3.2), chronic kidney disease $(2.6,1.9$ to 3.6$)$, and any increase in body mass index (BMI) (eg, for BMI >40: 2.5, 1.8 to 3.4). The strongest risks for critical illness besides age were associated with heart failure $(1.9,1.4$ to 2.5$), \mathrm{BMI}>40(1.5,1.0$ to 2.2), and male sex (1.5, 1.3 to 1.8). Admission oxygen saturation of $\langle 88 \%(3.7,2.8$ to 4.8$)$, troponin level $>1$ $(4.8,2.1$ to 10.9$)$, C reactive protein level $>200$ (5.1, 2.8 to 9.2), and D-dimer level $>2500$ (3.9, 2.6 to 6.0) were, however, more strongly associated with critical illness than age or comorbidities. Risk of critical illness decreased significantly over the study period. Similar associations were found for mortality alone.

\section{CONCLUSIONS}

Age and comorbidities were found to be strong predictors of hospital admission and to a lesser extent of critical illness and mortality in people with covid-19; however, impairment of oxygen on admission and markers of inflammation were most strongly associated with critical illness and mortality. Outcomes seem to be improving over time, potentially suggesting improvements in care.

\section{Introduction}

On 31 December 2019, China announced a cluster of novel pneumonia-like illness. The causative organism, severe acute respiratory syndrome coronavirus 2 (SARS-Cov-2), has to date infected more than 4.8 million people globally and been responsible for more than 318000 known deaths from coronavirus disease 2019 (covid-19). The virus has resulted in a pandemic.

Though several reports from China, ${ }^{12}$ Italy, ${ }^{34}$ and most recently the United States ${ }^{5-7}$ have described some characteristics of people with covid-19, little is understood about factors associated with hospital admission and severe disease. Studies so far have included few people with severe outcomes ${ }^{18-12}$ or have not compared people with severe disease with those with less virulent disease, ${ }^{13-15}$ making it difficult to assess characteristics associated with poor outcomes. Few large studies have conducted multivariable regression to help identify the strongest risk factors.

New York City is now the epicenter of the covid-19 outbreak in the US, with more than 190000 known cases in the city and more than 15000 confirmed 
deaths as of 19 May: more than anywhere else in the country. ${ }^{16}$ We describe the characteristics of people with covid-19 treated at a large quaternary academic health system in New York City and Long Island, and the association of these characteristics with adverse outcomes.

\section{Methods}

\section{Study setting}

The study was conducted at NYU Langone Health, which includes more than 260 outpatient office sites and four acute care hospitals (Tisch Hospital and NYU Langone Orthopedic Hospital in Manhattan, NYU Langone Hospital - Brooklyn in Brooklyn, and NYU Winthrop on Long Island), ranging from a quaternary care hospital to a safety net institution. ${ }^{17}$ As the epidemic evolved, the health system added intensive care unit (ICU) beds and inpatient capacity, resulting in a peak of about 394 ICU beds and 1357 non-ICU beds.

\section{Study cohort}

We identified all patients who were tested for SARSCov-2 between 1 March 2020 and 8 April 2020. We then created a cohort of those with confirmed covid-19, defined as a positive result on real time reverse transcriptase polymerase chain reaction (RTPCR) assay of nasopharyngeal or oropharyngeal swab specimens. Initial tests were conducted by the New York City Department of Health and Mental Hygiene; as of 16 March, tests were conducted in our clinical laboratory using the Roche SARS-CoV2 assay in the Cobas 6800 instruments through emergency use authorization granted by the US Food and Drug Administration. On 31 March, we added testing using the SARS-CoV2 Xpert Xpress assay in the Cepheid GeneXpert instruments also under emergency use authorization by the FDA. The targets amplified by these assays are the ORF1/a and $\mathrm{E}$ genes in the Roche Cobas assay and N2 and E genes in the Cepheid XpertXpress. After 16 March, only nasopharyngeal samples were collected and tested.

Testing was performed on people presenting to the emergency department who were likely to be admitted with any symptom or sign consistent with covid-19, including fever, cough, shortness of breath, fatigue, gastrointestinal problems, syncope, known exposure to a patient positive for covid-19, or clinician concern. In addition, ambulatory testing was available by appointment with clinician's referral until 26 March 2020, when New York state recommended restricting testing of people with mild or moderate illness. Outpatient testing of symptomatic or concerned employees remained available throughout the study period. Repeat testing of negative specimens was conducted at clinician discretion. If testing was repeated and discordant (ie, negative test followed by a positive test), we used the positive result.

From the covid-19 cohort we excluded 287 people who were not admitted to hospital, were missing all data besides age and sex, and had no previous visits within the health system. We obtained complete follow up on the covid-19 cohort through 5 May 2020.

\section{Data sources}

Study data were obtained from the electronic health record (Epic Systems, Verona, WI), which is an integrated electronic health record including all inpatient and outpatient visits in the health system. For data on tobacco use, body mass index (BMI), and comorbidities, we included any data in the electronic health record, including data entered during previous inpatient or outpatient visits in the problem list, medical history section, or on encounter diagnoses.

\section{Main outcomes}

We assessed three primary outcomes: inpatient hospital admissions; critical illness, defined as a composite of care in the intensive care unit, use of mechanical ventilation, discharge to hospice, or death; and discharge to hospice or death among those admitted to hospital. We assessed outcomes longitudinally over the entire study period, not just at the time of the initial testing event. For patients with multiple visits, the most severe outcome was assigned. For instance, patients who did not need hospital admission at the time of initial testing but were later admitted were assigned to the hospital group. Similarly, patients who were initially admitted and discharged and then readmitted requiring invasive ventilation were assigned to the critical illness group.

\section{Predictors}

We obtained several variables from the electronic health record: age at time of testing, sex, race/ ethnicity as reported by the patient (aggregated into non-Hispanic white, non-Hispanic African-American, Asian, Hispanic, other/multiracial, and unknown), and history of hypertension, hyperlipidemia, coronary artery disease, heart failure, pulmonary disease (defined by chronic obstructive pulmonary disease or asthma), malignancy (excluding non-metastatic non-melanoma skin cancer), diabetes, and obesity (defined by most recent BMI). We also obtained vital signs and the first set of laboratory results when available. For multivariable modeling, we grouped vital sign and laboratory results into categories by degree of abnormality based on clinical judgment because of non-linear associations with outcome. We selected these predictors based on previous published literature ${ }^{15}$ and our clinical experience of patients with covid-19.

\section{Statistical analysis}

We used descriptive statistics to characterize each cohort of patients: those not admitted to hospital, all those admitted, those admitted without critical illness, and those with critical illness (care in ICU, mechanical ventilation, discharge to hospice, or death). We then fitted multivariable logistic regression models with admission and with critical illness as the outcomes to identify factors associated with those outcomes. In analyses using hospital admission as the outcome, we included only patient characteristics and comorbidities, since $77 \%$ of the patients who were 
not admitted were evaluated in ambulatory testing centers and did not have vitals or laboratory studies collected. For the critical illness analyses, we included the above predictors and for one of the models added temperature and oxygen saturation on presentation, as well as the first result of $\mathrm{C}$ reactive protein, $\mathrm{D}$-dimer, ferritin, procalcitonin, and troponin when obtained. We included all selected predictors based on a priori clinical significance after testing for collinearity using the variance inflation factor and ensuring none had a variance inflation factor greater than $2 .^{18}$ We also tested for overall multicollinearity among all variables simultaneously using the determinant of correlation matrix implemented in R's mctest library and found no significant results. ${ }^{19}$

For the admission model, we included all patients testing positive (excluding the 287 patients with no data besides age and sex). We constructed two models for association with critical illness. First, we constructed a model restricted to patients admitted to hospital, including all personal and comorbidity predictors, and a random effect for hospital to account for clustering by facility. Second, we added to that model vital signs and the first set of laboratory results, to assess clinical associations with critical illness among patients admitted to hospital. We excluded from the second model four patients who died in the emergency department before vital signs or laboratory results could be collected. We obtained odds ratios from the models and profiled confidence intervals for the odds ratios using the approach of Venables and Ripley, ${ }^{20}$ since assuming normality of the maximum likelihood estimate to estimate Wald-type confidence intervals can lead to biased estimates. ${ }^{21}$ We also calculated average marginal effects for each predictor by using the margins library in $\mathrm{R}$, which uses a discrete first difference in predicted outcomes to obtain the average marginal effect.

Finally, we fitted a competing risk model for the mortality or hospice outcome with time from first positive test result as the start point, including only patients admitted to hospital. ${ }^{22}$ We considered discharge from hospital to be a competing risk, since mortality data are limited after that point unless the patient is readmitted to our system (in which case the newest hospital admission would be included). Patients still in hospital as of 5 May 2020 were counted as censored. The model was fitted with the $\mathrm{R}$ library cmprisk, ${ }^{23}$ and the proportionality assumption was checked with the goffte library. ${ }^{24}$ We fitted two competing risk models, one adjusting for personal characteristics and comorbidities, and one adding admission vitals and laboratory studies.

All statistical analyses were conducted with $\mathrm{R}$, version 3.6.3. All analyses used two sided statistical tests and we considered a $\mathrm{P}$ value less than 0.05 to be statistically significant without adjustment for multiple testing.

\section{Patient and public involvement}

Patients and the public were not a priori involved in the design and conduct of the study, the choice of outcomes, recruitment, or planned dissemination. However, we incorporated many comments from the public on an earlier preprint version of the paper into the final analysis.

\section{Results}

During the study period, the health system tested 11544 people for severe acute respiratory syndrome coronavirus 2 (SARS-Cov-2). Of those tested, 5566 (48.2\%) were positive and 287 were excluded for lack of data. Of the remaining 5279 patients testing positive, 2538 (48.1\%) were treated only as outpatients through the end of the study period, and 2741 (51.9\%) required admission to hospital. Nearly all those admitted to the hospital $(2729,99.6 \%)$ experienced a study outcome: 1739/2741 (63.4\%) were discharged without critical illness and 990/2741 (36.1\%) experienced critical illness, including 665/2741 (24.3\%) who were discharged to a hospice or died to date.

Among the 990 patients with critical illness, 647 (65.4\%) required mechanical ventilation, 102 (10.3\%) required intensive care without mechanical ventilation, and $241(24.3 \%)$ were discharged to a hospice or died without either intensive care or mechanical ventilation. Figure 1 shows the final outcomes to date for each subgroup.

\section{Characteristics of study population}

The median age of the study population that tested positive for covid-19 was 54 years (interquartile range 38-66 years), and 2615 (49.5\%) were men. A total of 1195 (22.6\%) had diabetes, 1865 (35.3\%) were obese (BMI $\geq 30)$, and $2752(52.1 \%)$ had any form of cardiovascular disease. Among patients admitted to hospital, the median length of stay was 7 days (interquartile range 3-13; full range 0-52 days). Median length of stay for those still in hospital with critical illness ( $n=160)$ was 36 days (32-40, full range 3-52 days). See appendix table $\mathrm{S} 1$ for characteristics of those who tested negative. Among tests performed in the emergency department, $83.9 \%$ were for patients who were admitted and $16.1 \%$ were for patients who were discharged (see appendix tables S2 and S3). Appendix table S4 shows the characteristics of patients seen in the emergency department for suspected covid-19 but who were not tested.

People admitted to hospital were more likely to be men (61.2\% $v 36.9 \%)$ and were considerably more likely to have comorbidities than people not admitted (any comorbidity, $79.7 \% \quad v \quad 44.8 \%$ ), particularly cardiovascular disease $(70.6 \% \quad v 32.2 \%)$, diabetes $(34.7 \% \vee 9.7 \%)$, and chronic kidney disease $(21.2 \%$ $v$ 2.6\%; table 1). Differences in sex and comorbidities between admitted patients experiencing critical illness and those who did not were much smaller. Among these patients, differences in clinical presentation and laboratory results were more prominent. Patients with critical illness more often presented with hypoxia (initial oxygen saturation 25th centile $86 \% \vee 92 \%$ ), and had higher initial levels of $\mathrm{C}$ reactive protein (median $136.3 v$ 89.1), D-dimer (median $528 v$ 324), 


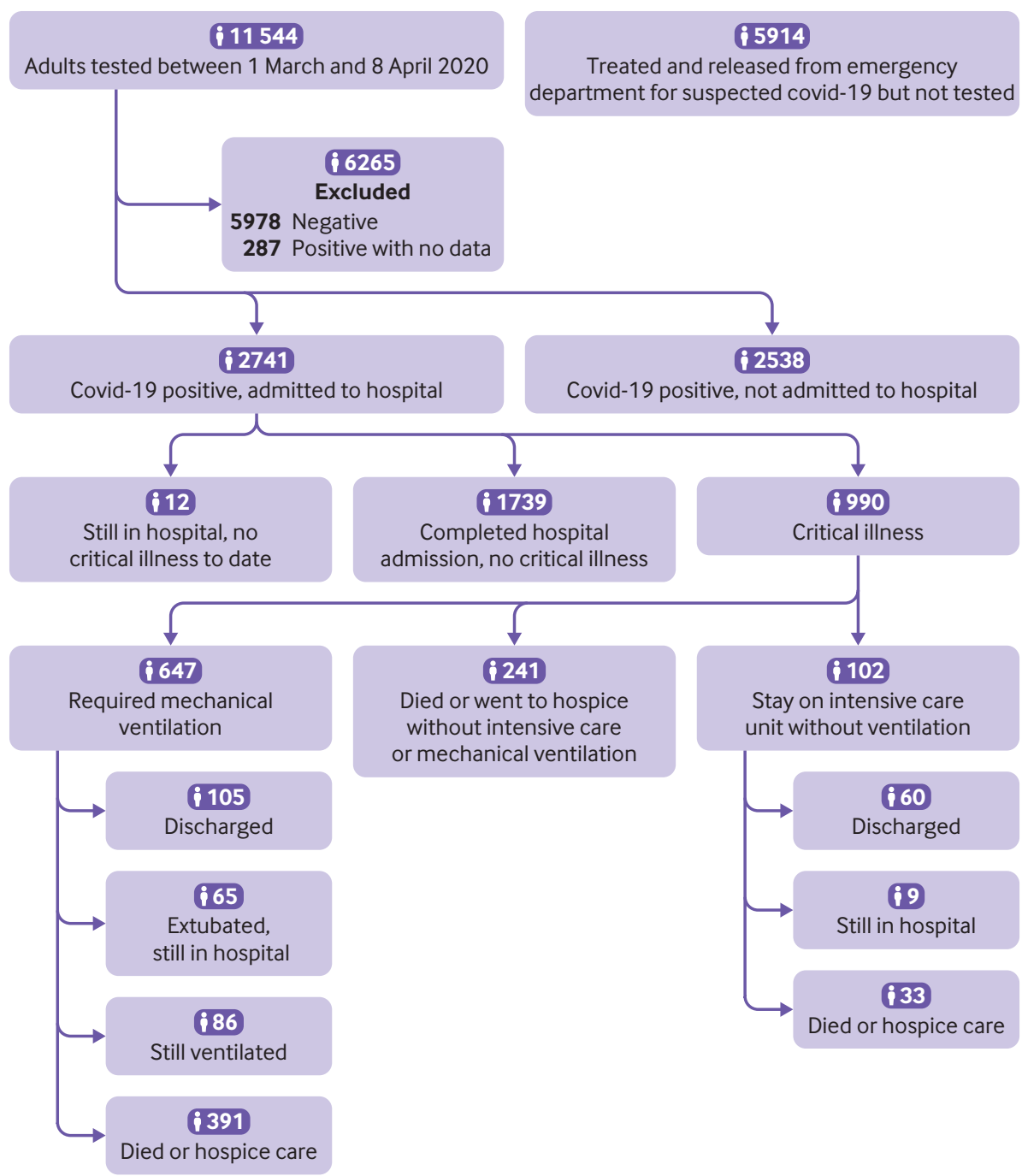

Fig 1 | Flow diagram of included participants. Covid-19=coronavirus disease 2019

ferritin (median $925 v$ 613), procalcitonin (0.27 $v$ $0.10)$, and troponin (0.07 $v 0.02$; table 2$)$.

\section{Predictors of hospital admission}

In multivariable analysis of the full covid-19 positive cohort, the factors most strongly associated with hospital admission were age, including 75 years or older (odds ratio 37.9, 95\% confidence interval 26.1 to 56.0; average marginal effect $58 \%$ ) and 65 to 74 years $(8.7,8.7$ to $11.2,40 \%)$, heart failure $(4.4,2.6$ to $8.0,22 \%)$, male sex $(2.8,2.4$ to $3.2,16 \%)$, chronic kidney disease (2.6, 1.9 to $3.6,14 \%$ ), and any increase in BMI (eg, BMI $>40$ : $2.5,1.8$ to $3.4,14 \%$ ). Also significant was hypertension. Hyperlipidemia was associated with a lower risk of hospital admission $(0.6,0.5$ to $0.7,-7 \%)$ as was former or current smoking status; however, unknown smoking status was associated with a higher risk $(1.4,1.2$ to 1.8 , $5 \%$; table 1 ). A sensitivity analysis adding patients seen in the emergency department for suspected covid-19 but not tested produced similar results (appendix table S5), as did a different sensitivity analysis restricting patients who were not admitted to hospital to those tested in the emergency department (appendix table S6).
Among people admitted to hospital with covid-19, the factors most associated with critical illness were age, including 75 years or older (odds ratio 3.5, 95\% confidence interval 2.5 to 4.8 ) and 65 to 74 years (2.9, 2.1 to 4.0$)$, heart failure $(1.9,1.4$ to 2.5$)$, BMI greater than 40 (1.5, 1.0 to 2.2$)$, and male sex $(1.5,1.3$ to 1.8$)$, with diabetes also significant (table 3 ). Risk of critical illness declined progressively as the study period progressed, with the lowest being in the last week $(0.4,0.2$ to 0.6$)$.

Being of self-reported Hispanic ethnicity was associated with an increased risk of hospital admission but not of critical illness; the increased risk of admission was eliminated once emergency department treat-andrelease patients were included (appendix table S5). Non-Hispanic African-American patients had a risk of admission similar to white patients and a lower risk of critical illness (0.7, 0.5 to 0.9$)$.

After adding admission vital signs and first set of laboratory results to the critical illness model, only age, heart failure, and BMI greater than 40 remained associated with significant risks; in this model, the factors most associated with critical illness were oxygen saturation on admission less than $88 \%$ (3.7, 2.8 to 4.8$)$, 


\begin{tabular}{|c|c|c|c|c|c|c|c|}
\hline \multirow[b]{2}{*}{ Characteristics } & \multirow[b]{2}{*}{$\begin{array}{l}\text { Overall } \\
(n=5279)\end{array}$} & \multirow{2}{*}{$\begin{array}{l}\text { Not admitted } \\
\text { to hospital } \\
(n=2538)\end{array}$} & \multirow{2}{*}{$\begin{array}{l}\text { Admitted } \\
\text { to hospital } \\
\text { ( } n=2741)\end{array}$} & \multicolumn{3}{|c|}{ Risk of hospital admission } & \multirow{2}{*}{$\begin{array}{l}\text { Average } \\
\text { marginal } \\
\text { effect (\%) }\end{array}$} \\
\hline & & & & $\begin{array}{l}\text { Unadjusted odds ratio } \\
(95 \% \mathrm{Cl})\end{array}$ & $\begin{array}{l}\text { Adjusted odds ratio } \\
(95 \% \mathrm{Cl})\end{array}$ & $P$ value & \\
\hline \multicolumn{8}{|l|}{ Week: } \\
\hline $10(2-8$ March $)$ & $5(0.1)$ & $1(0.0)$ & $4(0.1)$ & \multirow{2}{*}{ Reference } & \multirow{2}{*}{ Reference } & \multirow{2}{*}{-} & \multirow{2}{*}{-} \\
\hline 11 (9-15 March) & $106(2.0)$ & $43(1.7)$ & $63(2.3)$ & & & & \\
\hline 12 (16-22 March) & $1023(19.4)$ & $633(24.9)$ & $390(14.2)$ & $0.40(0.27$ to 0.60$)$ & $0.4(0.24$ to 0.67$)$ & $<0.001$ & -14 \\
\hline 13 (23-29 March) & $1271(24.1)$ & $406(16.0)$ & $865(31.6)$ & 1.40 (0.93 to 2.08$)$ & $1.42(0.85$ to 2.34$)$ & 0.18 & 5 \\
\hline 14 (30 March to 5 April) & $2083(39.5)$ & $1055(41.6)$ & $1028(37.5)$ & $0.64(0.43$ to 0.94$)$ & $0.78(0.47$ to 1.27$)$ & 0.32 & -4 \\
\hline 15 (6-8 April) & $791(15.0)$ & $400(15.8)$ & $391(14.3)$ & $0.64(0.43$ to 0.96$)$ & $0.66(0.39$ to 1.1$)$ & 0.11 & -6 \\
\hline Median (interquartile range) age (years) & $54(38-66)$ & $42(32-55)$ & $63(51-74)$ & - & - & - & - \\
\hline \multicolumn{8}{|l|}{ Age (years): } \\
\hline $19-44$ & $1846(35.0)$ & $1409(55.5)$ & $437(15.9)$ & Reference & Reference & - & - \\
\hline $45-54$ & $902(17.1)$ & $492(19.4)$ & $410(15.0)$ & $2.69(2.27$ to 3.18$)$ & $2.14(1.76$ to 2.59$)$ & $<0.001$ & 14 \\
\hline $55-64$ & $1021(19.3)$ & $416(16.4)$ & $605(22.1)$ & 4.69 (3.98 to 5.53$)$ & 3.67 (3.01 to 4.48$)$ & $<0.001$ & 24 \\
\hline $65-74$ & 797 (15.1) & $176(6.9)$ & $621(22.7)$ & 11.38 (9.33 to 13.88$)$ & $8.7(6.77$ to 11.22$)$ & $<0.001$ & 40 \\
\hline$\geq 75$ & $713(13.5)$ & $45(1.8)$ & $668(24.4)$ & 47.84 (34.73 to 65.91$)$ & 37.87 (26.1 to 56.03$)$ & $<0.001$ & 58 \\
\hline Men & 2615 (49.5) & 937 (36.9) & $1678(61.2)$ & 2.70 (2.41 to 3.02$)$ & $2.76(2.39$ to 3.2$)$ & $<0.001$ & 16 \\
\hline \multicolumn{8}{|l|}{ Race/ethnicity: } \\
\hline Non-Hispanic white & $2003(37.9)$ & $909(35.8)$ & $1094(39.9)$ & Reference & Reference & - & - \\
\hline Non-Hispanic African-American & $835(15.8)$ & $443(17.5)$ & $392(14.3)$ & $0.74(0.63$ to 0.86$)$ & 0.81 (0.65 to 1.01$)$ & 0.06 & -3 \\
\hline Asian & $383(7.3)$ & $196(7.7)$ & $187(6.8)$ & 0.79 (0.64 to 0.99) & $1.29(0.97$ to 1.72$)$ & 0.08 & 4 \\
\hline Hispanic & $1330(25.2)$ & $599(23.6)$ & $731(26.7)$ & 1.01 (0.88 to 1.17$)$ & $1.63(1.35$ to 1.97$)$ & $<0.001$ & 8 \\
\hline Other/multiracial & $397(7.5)$ & $172(6.8)$ & $225(8.2)$ & 1.09 (0.88 to 1.35$)$ & $1.6(1.21$ to 2.11$)$ & $<0.001$ & 7 \\
\hline Unknown & $331(6.3)$ & $219(8.6)$ & $112(4.1)$ & $0.43(0.33$ to 0.54$)$ & $0.89(0.65$ to 1.23$)$ & 0.49 & -2 \\
\hline \multicolumn{8}{|l|}{ Smoking status: } \\
\hline Never & 3268 (61.9) & $1678(66.1)$ & $1590(58.0)$ & Reference & Reference & - & - \\
\hline Former & $902(17.1)$ & $337(13.3)$ & $565(20.6)$ & 1.77 (1.52 to 2.06$)$ & $0.69(0.56$ to 0.85$)$ & $<0.001$ & -6 \\
\hline Current & $288(5.5)$ & $147(5.8)$ & $141(5.1)$ & 1.01 (0.80 to 1.29$)$ & $0.59(0.43$ to 0.81$)$ & 0.001 & -8 \\
\hline Unknown & $821(15.6)$ & $376(14.8)$ & $445(16.2)$ & 1.25 (1.07 to 1.46$)$ & $1.43(1.16$ to 1.75$)$ & $<0.001$ & 5 \\
\hline \multicolumn{8}{|l|}{ BMI: } \\
\hline$<25$ & $1406(26.6)$ & $756(29.8)$ & $650(23.7)$ & Reference & Reference & - & - \\
\hline $25.0-29.9$ & 1769 (33.5) & $830(32.7)$ & $939(34.3)$ & $1.32(1.14$ to 1.51$)$ & $1.3(1.07$ to 1.57$)$ & 0.007 & 4 \\
\hline $30.0-39.9$ & $1554(29.4)$ & $655(25.8)$ & $899(32.8)$ & $1.60(1.38$ to 1.85$)$ & $1.8(1.47$ to 2.2$)$ & $<0.001$ & 9 \\
\hline$\geq 40$ & $311(5.9)$ & $126(5.0)$ & $185(6.7)$ & 1.71 (1.33 to 2.19$)$ & $2.45(1.78$ to 3.36$)$ & $<0.001$ & 14 \\
\hline Unknown & $239(4.5)$ & $171(6.7)$ & $68(2.5)$ & 0.46 (0.34 to 0.63$)$ & $0.47(0.31$ to 0.69$)$ & $<0.001$ & -11 \\
\hline Any chronic condition* & $3323(62.9)$ & $1138(44.8)$ & $2185(79.7)$ & - & - & - & - \\
\hline Any cardiovascular condition*: & $2752(52.1)$ & $818(32.2)$ & $1934(70.6)$ & - & - & - & - \\
\hline Coronary artery disease & $704(13.3)$ & $102(4.0)$ & $602(22.0)$ & $6.72(5.40$ to 8.35$)$ & $1.08(0.81$ to 1.44$)$ & 0.60 & 1 \\
\hline Heart failure & $367(7.0)$ & $17(0.7)$ & $350(12.8)$ & 21.71 (13.30 to 35.43$)$ & $4.43(2.59$ to 8.04$)$ & $<0.001$ & 22 \\
\hline Hyperlipidemia & $1714(32.5)$ & $552(21.7)$ & $1162(42.4)$ & $2.65(2.35$ to 2.99$)$ & $0.62(0.52$ to 0.74$)$ & $<0.001$ & -7 \\
\hline Hypertension & $2256(42.7)$ & 557 (21.9) & $1699(62.0)$ & $5.80(5.14$ to 6.55$)$ & 1.78 (1.49 to 2.12$)$ & $<0.001$ & 9 \\
\hline Diabetes & $1195(22.6)$ & $245(9.7)$ & $950(34.7)$ & $4.96(4.26$ to 5.79$)$ & 2.24 (1.84 to 2.73$)$ & $<0.001$ & 12 \\
\hline Asthma or chronic obstructive pulmonary disease & $786(14.9)$ & $333(13.1)$ & $453(16.5)$ & $1.31(1.13$ to 1.53$)$ & $1.08(0.88$ to 1.33$)$ & 0.47 & 1 \\
\hline Chronic kidney disease & $647(12.3)$ & $66(2.6)$ & $581(21.2)$ & 10.08 (7.76 to 13.08$)$ & $2.6(1.89$ to 3.61$)$ & $<0.001$ & 14 \\
\hline Cancer & $403(7.6)$ & $108(4.3)$ & $295(10.8)$ & $2.71(2.16$ to 3.41$)$ & 0.88 (0.65 to 1.19$)$ & 0.41 & -2 \\
\hline
\end{tabular}

troponin level greater than 1 (4.8, 2.1 to 10.9$)$, C reactive protein level greater than 200 (5.1, 2.8 to 9.2), and D-dimer level greater than 2500 (3.9, 2.6 to 6.0; table 3).

The competing risk mortality analysis showed similar characteristics to confer increased hazard as the critical illness model, but fewer were significant. The hazard ratio increased proportionally by age: 10.3 (95\% confidence interval 6.4 to 16.8 ) for age 75 years or older. Other significant factors included heart failure (1.8, 1.4 to 2.2$)$, male sex $(1.3,1.1$ to 1.5$)$, and cancer $(1.3,1.1$ to 1.6). Vital signs and laboratory results on presentation carried a significant additional hazard, chiefly hypoxia on presentation $(2.0,1.6$ to 2.5 for oxygen saturation $<88 \%$ ), C reactive protein (all abnormal levels had hazard ratios $>3.5)$, D-dimer $(2.2,1.6$ to 3.0 for first result $>2500)$, and troponin $(2.1,1.4$ to 3.2 for first result $>1$ ) (table 4). Representative cumulative incidence functions are shown in figure 2 (age groupings), figure 3 (heart failure, cancer, diabetes, and men), and figures 4 and 5 (admission oxygen saturation, D-dimer levels, C reactive protein and lymphocyte count).

\section{Discussion}

In this report, we describe the characteristics of adults with laboratory confirmed coronavirus disease 2019 (covid-19) in New York City. Of 5279 adults, 2741 required hospital admission; and 990 required intensive care or mechanical ventilation, were discharged to hospice care, or died. A total of $94 \%$ of patients admitted to hospital have been discharged alive or to hospice care or have died, providing robust final outcome results. We find particularly strong associations of older age, male sex, heart failure, chronic kidney disease, and obesity with 


\begin{tabular}{|c|c|c|c|}
\hline Characteristics & $\begin{array}{l}\text { Inpatients with outcomes } \\
(n=2729)\end{array}$ & $\begin{array}{l}\text { Discharged, no critical } \\
\text { illness }(n=1739)\end{array}$ & Critical illness $(n=990)$ \\
\hline \multicolumn{4}{|l|}{ Week: } \\
\hline 10 (2-8 March) & $4(0.1)$ & $3(0.2)$ & $1(0.1)$ \\
\hline 11 (9-15 March) & $63(2.3)$ & $31(1.8)$ & $32(3.2)$ \\
\hline 12 (16-22 March) & $389(14.3)$ & $231(13.3)$ & $158(16.0)$ \\
\hline 13 (23-29 March) & $863(31.6)$ & $544(31.3)$ & $319(32.2)$ \\
\hline 14 (30 March to 5 April) & $1021(37.4)$ & $654(37.6)$ & $367(37.1)$ \\
\hline 15 (6-8 April) & $389(14.3)$ & $276(15.9)$ & $113(11.4)$ \\
\hline Median (interquartile range) age (years) & $63(51-74)$ & $60(48-71)$ & $68(58-78)$ \\
\hline \multicolumn{4}{|l|}{ Age (years): } \\
\hline $19-44$ & $435(15.9)$ & $344(19.8)$ & $91(9.2)$ \\
\hline $45-54$ & $407(14.9)$ & $310(17.8)$ & $97(9.8)$ \\
\hline $55-64$ & $602(22.1)$ & $391(22.5)$ & $211(21.3)$ \\
\hline $65-74$ & $619(22.7)$ & $355(20.4)$ & $264(26.7)$ \\
\hline$\geq 75$ & $666(24.4)$ & 339 (19.5) & $327(33.0)$ \\
\hline Men & $1672(61.3)$ & $1016(58.4)$ & $656(66.3)$ \\
\hline \multicolumn{4}{|l|}{ Race/ethnicity: } \\
\hline Non-Hispanic white & 1089 (39.9) & $654(37.6)$ & $435(43.9)$ \\
\hline Non-Hispanic African-American & $390(14.3)$ & $278(16.0)$ & $112(11.3)$ \\
\hline Asian & $185(6.8)$ & $107(6.2)$ & $78(7.9)$ \\
\hline Hispanic & $728(26.7)$ & $493(28.3)$ & $235(23.7)$ \\
\hline Other/multiracial & $225(8.2)$ & $141(8.1)$ & $84(8.5)$ \\
\hline Unknown & $112(4.1)$ & $66(3.8)$ & $46(4.6)$ \\
\hline \multicolumn{4}{|l|}{ Smoking status: } \\
\hline Never & $1584(58.0)$ & $1067(61.4)$ & $517(52.2)$ \\
\hline Former & $561(20.6)$ & $325(18.7)$ & $236(23.8)$ \\
\hline Current & $141(5.2)$ & $97(5.6)$ & $44(4.4)$ \\
\hline Unknown & $443(16.2)$ & $250(14.4)$ & $193(19.5)$ \\
\hline \multicolumn{4}{|l|}{ BMI: } \\
\hline$<25$ & $648(23.7)$ & $382(22.0)$ & $266(26.9)$ \\
\hline 25.0-29.9 & $932(34.2)$ & $608(35.0)$ & $324(32.7)$ \\
\hline $30.0-39.9$ & $896(32.8)$ & $592(34.0)$ & $304(30.7)$ \\
\hline$\geq 40$ & $185(6.8)$ & $115(6.6)$ & $70(7.1)$ \\
\hline Unknown & $68(2.5)$ & $42(2.4)$ & $26(2.6)$ \\
\hline Any chronic condition* & $2176(79.7)$ & $1343(77.2)$ & $833(84.1)$ \\
\hline Any cardiovascular condition*: & $1927(70.6)$ & $1166(67.1)$ & $761(76.9)$ \\
\hline Coronary artery disease & $602(22.1)$ & $325(18.7)$ & $277(28.0)$ \\
\hline Heart failure & $349(12.8)$ & $160(9.2)$ & $189(19.1)$ \\
\hline Hyperlipidemia & $1157(42.4)$ & $692(39.8)$ & $465(47.0)$ \\
\hline Median (interquartile range) LDL cholesterol & $64(46-86)$ & $71(52-91)$ & $56(39-75)$ \\
\hline Hypertension & $1693(62.0)$ & $1013(58.3)$ & $680(68.7)$ \\
\hline Diabetes & $950(34.7)$ & $561(32.0)$ & 389 (39.3) \\
\hline Asthma or chronic obstructive pulmonary disease & $453(16.5)$ & $284(16.2)$ & $169(17.1)$ \\
\hline Chronic kidney disease & $580(21.3)$ & $321(18.5)$ & $259(26.2)$ \\
\hline Cancer & $292(10.7)$ & $154(8.9)$ & $138(13.9)$ \\
\hline \multicolumn{4}{|l|}{ Measures at presentation: } \\
\hline Median (interquartile range) temperature $\left({ }^{\circ} \mathrm{C}\right.$ ) & $37.4(36.9-38.2)$ & $37.4(36.9-38.2)$ & $37.4(36.9-38.2)$ \\
\hline Temperature $\geq 38^{\circ} \mathrm{C}$ & $846(31.0)$ & $533(30.6)$ & $313(31.6)$ \\
\hline Median (interquartile range) oxygen saturation & $94(90-96)$ & $95(92-97) \dagger$ & $92(86-95) \ddagger$ \\
\hline Oxygen saturation $<88 \%$ & $422(15.5)$ & $136(7.8)$ & $286(28.9)$ \\
\hline \multicolumn{4}{|c|}{ Median (interquartile range) for first measurements: } \\
\hline Absolute lymphocyte count $\left(10^{3} / \mu \mathrm{L} ; \mathrm{SI} 10^{9} / \mathrm{L}\right)$ & $0.8(0.6-1.2)$ & $0.9(0.6-1.2)$ & $0.8(0.5-1.1)$ \\
\hline Missing & $34(1.2)$ & $17(1.0)$ & $17(1.7)$ \\
\hline Creatinine $(\mathrm{mg} / \mathrm{dL}) \S$ & $1.0(0.80-1.39)$ & $0.95(0.79-1.23)$ & $1.11(0.88-1.61)$ \\
\hline Missing & $55(2.0)$ & $38(2.2)$ & $17(1.7)$ \\
\hline Alanine aminotransferase (units/L)* & $34(23-55)$ & $33.5(22-55)$ & $36(24-57)$ \\
\hline Missing & $115(4.2)$ & $89(5.1)$ & $26(2.6)$ \\
\hline Aspartate aminotransferase (units/L)* & $46(32.0-69.0)$ & $42(29.5-62.0)$ & $53(36.0-82.0)$ \\
\hline Missing & $163(6.0)$ & $112(6.4)$ & $51(5.2)$ \\
\hline C reactive protein $(\mathrm{mg} / \mathrm{L})$ ๆ & $108.3(53.3-169.0)$ & $89.1(41.9-148.0)$ & $136.3(85.8-204.2)$ \\
\hline Missing & $165(6.0)$ & $123(7.1)$ & $42(4.2)$ \\
\hline D-dimer (ng/mL; SI $\mu \mathrm{g} / \mathrm{L})$ & $386.5(237.0-713.8)$ & $324(208.0-545.0)$ & $528(319.0-1174.0)$ \\
\hline Missing & $373(13.7)$ & $280(16.1)$ & $93(9.4)$ \\
\hline Ferritin (ng/mL; SI $\mu \mathrm{g} / \mathrm{L})$ & $710.2(348.0-1461.2)$ & $613(305.0-1291.5)$ & $925(468.2-1716.7)$ \\
\hline Missing & $218(8.0)$ & $164(9.4)$ & $54(5.5)$ \\
\hline Procalcitonin (ng/mL; SI $\mu \mathrm{g} / \mathrm{L})$ & $0.14(0.06-0.40)$ & $0.1(0.05-0.23)$ & $0.27(0.12-0.82)$ \\
\hline Missing & $191(7.0)$ & $147(8.5)$ & $44(4.4)$ \\
\hline
\end{tabular}




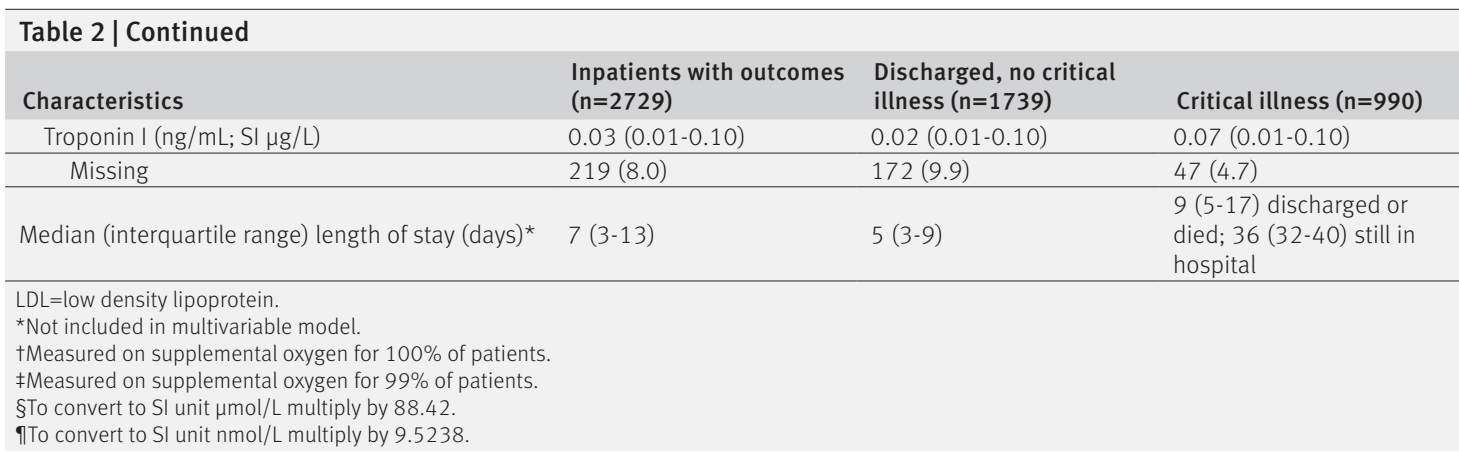

\begin{tabular}{|c|c|c|c|c|c|}
\hline \multirow[b]{2}{*}{ Characteristics } & \multirow[b]{2}{*}{$\begin{array}{l}\text { Unadjusted odds ratio } \\
(95 \% \mathrm{Cl})(\mathrm{n}=2725)\end{array}$} & \multicolumn{2}{|c|}{$\begin{array}{l}\text { Excluding vital signs and } \\
\text { laboratory results }(n=2725)\end{array}$} & \multicolumn{2}{|c|}{$\begin{array}{l}\text { Including vital signs and } \\
\text { laboratory results }(n=2725)\end{array}$} \\
\hline & & $\begin{array}{l}\text { Adjusted odds ratio } \\
(95 \% \mathrm{Cl})\end{array}$ & $P$ value & $\begin{array}{l}\text { Adjusted odds ratio } \\
(95 \% \mathrm{Cl})\end{array}$ & $P$ value \\
\hline \multicolumn{6}{|l|}{ Week: } \\
\hline $10-11$ (2-15 March) & Reference & Reference & - & Reference & - \\
\hline 12 (16-22 March) & $0.70(0.42$ to 1.19$)$ & 0.76 (0.44 to 1.3$)$ & 0.32 & $0.49(0.25$ to 1.0$)$ & 0.04 \\
\hline $13(23-29$ March $)$ & $0.60(0.36$ to 0.99$)$ & $0.58(0.35$ to 1.0$)$ & 0.05 & $0.21(0.10$ to 0.4$)$ & $<0.001$ \\
\hline 14 (30 March to 5 April) & $0.58(0.35$ to 0.95$)$ & $0.55(0.33$ to 0.9$)$ & 0.03 & $0.16(0.08$ to 0.3$)$ & $<0.001$ \\
\hline 15 (6-8 April) & $0.42(0.25$ to 0.72$)$ & $0.37(0.21$ to 0.6$)$ & $<0.001$ & $0.08(0.04$ to 0.2$)$ & $<0.001$ \\
\hline \multicolumn{6}{|l|}{ Age (years): } \\
\hline $19-44$ & Reference & Reference & - & Reference & - \\
\hline $45-54$ & $1.18(0.86$ to 1.64$)$ & $1.12(0.80$ to 1.6$)$ & 0.50 & $0.78(0.54$ to 1.1$)$ & 0.21 \\
\hline $55-64$ & 2.01 (1.51 to 2.68$)$ & 2.04 (1.50 to 2.8$)$ & $<0.001$ & $1.32(0.93$ to 1.9$)$ & 0.12 \\
\hline $65-74$ & $2.81(2.12$ to 3.72$)$ & $2.88(2.09$ to 4.0$)$ & $<0.001$ & $1.73(1.19$ to 2.5$)$ & 0.004 \\
\hline$\geq 75$ & $3.64(2.76$ to 4.79$)$ & $3.46(2.46$ to 4.8$)$ & $<0.001$ & $2.32(1.57$ to 3.4$)$ & $<0.001$ \\
\hline Men & $1.40(1.19$ to 1.64$)$ & $1.54(1.29$ to 1.8$)$ & $<0.001$ & $1.06(0.85$ to 1.3$)$ & 0.60 \\
\hline \multicolumn{6}{|l|}{ Race/ethnicity: } \\
\hline Non-Hispanic white & Reference & Reference & - & Reference & - \\
\hline Non-Hispanic African-American & $0.60(0.47$ to 0.77$)$ & 0.67 (0.51 to 0.9$)$ & 0.004 & 0.57 (0.41 to 0.8$)$ & 0.001 \\
\hline Asian & $1.10(0.80$ to 1.51$)$ & $1.30(0.92$ to 1.8$)$ & 0.13 & 1.24 (0.82 to 1.9$)$ & 0.30 \\
\hline Hispanic & $0.72(0.59$ to 0.87$)$ & 0.93 (0.74 to 1.2$)$ & 0.54 & 0.89 (0.69 to 1.2$)$ & 0.38 \\
\hline Other/multiracial & $0.90(0.67$ to 1.21$)$ & 1.15 (0.84 to 1.6$)$ & 0.39 & 1.24 (0.86 to 1.8$)$ & 0.25 \\
\hline Unknown & 1.03 (0.69 to 1.53$)$ & $1.23(0.80$ to 1.9$)$ & 0.34 & $1.10(0.68$ to 1.8$)$ & 0.70 \\
\hline \multicolumn{6}{|l|}{ Smoking status: } \\
\hline Never & Reference & Reference & - & Reference & - \\
\hline Former & 1.50 (1.23 to 1.82$)$ & $1.06(0.85$ to 1.3$)$ & 0.59 & 1.05 (0.82 to 1.3$)$ & 0.72 \\
\hline Current & $0.94(0.65$ to 1.36$)$ & 0.77 (0.52 to 1.2$)$ & 0.21 & 0.82 (0.53 to 1.3$)$ & 0.39 \\
\hline Unknown & $1.58(1.27$ to 1.96$)$ & 1.52 (1.19 to 1.9$)$ & 0.001 & 1.42 (1.08 to 1.9$)$ & 0.01 \\
\hline \multicolumn{6}{|l|}{ BMI: } \\
\hline$<25$ & Reference & Reference & - & Reference & - \\
\hline $25.0-29.9$ & 0.77 (0.62 to 0.94$)$ & 0.86 (0.69 to 1.1$)$ & 0.18 & $0.94(0.73$ to 1.2$)$ & 0.65 \\
\hline $30.0-39.9$ & $0.73(0.59$ to 0.90$)$ & $0.98(0.77$ to 1.2$)$ & 0.85 & $1.11(0.85$ to 1.5$)$ & 0.44 \\
\hline$\geq 40$ & 0.87 (0.63 to 1.22$)$ & 1.52 (1.04 to 2.2$)$ & 0.03 & 1.71 (1.10 to 2.7$)$ & 0.02 \\
\hline Unknown & 0.86 (0.51 to 1.44$)$ & 0.80 (0.46 to 1.4$)$ & 0.43 & 1.05 (0.54 to 2.0$)$ & 0.89 \\
\hline Coronary artery disease & 1.69 (1.41 to 2.03$)$ & $0.96(0.77$ to 1.2$)$ & 0.76 & $0.92(0.71$ to 1.2$)$ & 0.56 \\
\hline Heart failure & 2.34 (1.87 to 2.94$)$ & 1.88 (1.43 to 2.5$)$ & $<0.001$ & 1.93 (1.40 to 2.6$)$ & $<0.001$ \\
\hline Hyperlipidemia & 1.35 (1.15 to 1.58$)$ & 0.94 (0.77 to 1.1$)$ & 0.50 & $0.93(0.75$ to 1.2$)$ & 0.51 \\
\hline Hypertension & 1.59 (1.34 to 1.87$)$ & 0.96 (0.77 to 1.2$)$ & 0.67 & $0.96(0.75$ to 1.2$)$ & 0.76 \\
\hline Diabetes & $1.38(1.17$ to 1.62$)$ & $1.24(1.03$ to 1.5$)$ & 0.03 & $1.23(0.99$ to 1.5$)$ & 0.06 \\
\hline $\begin{array}{l}\text { Asthma or chronic obstructive pulmonary } \\
\text { disease }\end{array}$ & $1.07(0.87$ to 1.32$)$ & $0.89(0.70$ to 1.1$)$ & 0.35 & 0.99 (0.76 to 1.3$)$ & 0.93 \\
\hline Chronic kidney disease & $1.57(1.30$ to 1.89$)$ & $1.07(0.85$ to 1.3$)$ & 0.54 & $0.73(0.55$ to 1.0$)$ & 0.04 \\
\hline Cancer & $1.68(1.31$ to 2.14$)$ & $1.23(0.95$ to 1.6$)$ & 0.12 & $1.30(0.95$ to 1.8$)$ & 0.10 \\
\hline \multicolumn{6}{|l|}{ Temperature on presentation $\left({ }^{\circ} \mathrm{C}\right)$ : } \\
\hline$<38$ & Reference & - & - & Reference & - \\
\hline $38-39$ & 1.05 (0.86 to 1.28$)$ & - & - & $1.08(0.85$ to 1.4$)$ & 0.52 \\
\hline$>39$ & $1.06(0.83$ to 1.37$)$ & - & - & $1.06(0.78$ to 1.4$)$ & 0.71 \\
\hline \multicolumn{6}{|l|}{ Oxygen saturation on presentation (\%): } \\
\hline$>92$ & Reference & - & - & Reference & - \\
\hline $88-92$ & $1.67(1.38$ to 2.03$)$ & - & - & $1.49(1.18$ to 1.9$)$ & 0.001 \\
\hline$<88$ & $5.57(4.42$ to 7.02$)$ & - & - & $3.67(2.78$ to 4.8$)$ & $<0.001$ \\
\hline
\end{tabular}




\begin{tabular}{|c|c|c|c|c|c|}
\hline \multirow[b]{2}{*}{ Characteristics } & \multirow[b]{2}{*}{$\begin{array}{l}\text { Unadjusted odds ratio } \\
(95 \% \mathrm{Cl})(\mathrm{n}=2725)\end{array}$} & \multicolumn{2}{|c|}{$\begin{array}{l}\text { Excluding vital signs and } \\
\text { laboratory results }(n=2725)\end{array}$} & \multicolumn{2}{|c|}{$\begin{array}{l}\text { Including vital signs and } \\
\text { laboratory results }(\mathrm{n}=2725)\end{array}$} \\
\hline & & $\begin{array}{l}\text { Adjusted odds ratio } \\
(95 \% \mathrm{Cl})\end{array}$ & $P$ value & $\begin{array}{l}\text { Adjusted odds ratio } \\
(95 \% \mathrm{Cl})\end{array}$ & $P$ value \\
\hline \multicolumn{6}{|c|}{ First lymphocyte count $\left(10^{3} / \mu \mathrm{L} ;\right.$ SI $\left.10^{9} / \mathrm{L}\right)$ : } \\
\hline$>1.2$ & Reference & - & - & Reference & - \\
\hline$>0.8-1.2$ & $1.14(0.90$ to 1.45$)$ & - & - & 1.09 (0.82 to 1.4$)$ & 0.57 \\
\hline $0.5-0.8$ & 1.55 (1.27 to 1.89$)$ & - & - & $1.19(0.93$ to 1.5$)$ & 0.17 \\
\hline$<0.5$ & 2.88 (2.20 to 3.78$)$ & - & - & $1.76(1.26$ to 2.5$)$ & 0.001 \\
\hline Missing & $1.90(0.91$ to 3.97$)$ & - & - & 4.76 (1.02 to 22.2$)$ & 0.05 \\
\hline \multicolumn{6}{|c|}{ First creatinine $(\mathrm{mg} / \mathrm{dL})^{\star}$ : } \\
\hline $0-1.1$ & Reference & - & - & Reference & \\
\hline$>1.1-2$ & $1.86(1.56$ to 2.23$)$ & - & - & $1.52(1.20$ to 1.9$)$ & 0.001 \\
\hline$>2$ & $2.90(2.25$ to 3.73$)$ & - & - & $1.66(1.11$ to 2.5$)$ & 0.01 \\
\hline Missing & $0.81(0.43$ to 1.54$)$ & - & - & $1.47(0.33$ to 6.7$)$ & 0.62 \\
\hline \multicolumn{6}{|c|}{ First $\mathrm{C}$ reactive protein $(\mathrm{mg} / \mathrm{L})$ t: } \\
\hline $0-15$ & Reference & - & - & Reference & - \\
\hline$>15-100$ & 2.85 (1.76 to 4.64$)$ & - & - & $2.35(1.37$ to 4.0$)$ & 0.002 \\
\hline$>100-200$ & $6.22(3.84$ to 10.08$)$ & - & - & $3.86(2.23$ to 6.7$)$ & $<0.001$ \\
\hline$>200$ & 10.12 (6.13 to 16.72$)$ & - & - & 5.09 (2.82 to 9.2$)$ & $<0.001$ \\
\hline Missing & $2.44(1.35$ to 4.41$)$ & - & - & $2.59(1.10$ to 6.1$)$ & 0.03 \\
\hline \multicolumn{6}{|c|}{ First D-dimer (ng/mL; SI $\mu \mathrm{g} / \mathrm{L})$ : } \\
\hline $0-250$ & Reference & - & - & Reference & - \\
\hline$>250-500$ & $2.22(1.75$ to 2.83$)$ & - & - & $1.58(1.21$ to 2.1$)$ & 0.001 \\
\hline$>500-1000$ & $3.70(2.84$ to 4.81$)$ & - & - & 2.26 (1.66 to 3.1$)$ & $<0.001$ \\
\hline$>1000-2500$ & 4.77 (3.39 to 6.71) & - & - & 2.37 (1.58 to 3.6$)$ & $<0.001$ \\
\hline$>2500$ & $9.45(6.65$ to 13.42$)$ & - & - & $3.93(2.60$ to 6.0$)$ & $<0.001$ \\
\hline Missing & $1.30(0.96$ to 1.77$)$ & - & - & 0.75 (0.48 to 1.2$)$ & 0.23 \\
\hline \multicolumn{6}{|c|}{ First ferritin (ng/mL; SI $\mu \mathrm{g} / \mathrm{L})$ : } \\
\hline $0-300$ & Reference & - & - & Reference & - \\
\hline$>300-500$ & $1.19(0.89$ to 1.59$)$ & - & - & $0.96(0.67$ to 1.4$)$ & 0.82 \\
\hline$>500-1000$ & $1.67(1.30$ to 2.14$)$ & - & - & $1.13(0.83$ to 1.5$)$ & 0.43 \\
\hline$>1000-2500$ & $2.17(1.70$ to 2.77$)$ & - & - & $1.14(0.83$ to 1.6$)$ & 0.41 \\
\hline$>2500$ & 2.98 (2.19 to 4.05$)$ & - & - & 1.40 (0.94 to 2.1$)$ & 0.10 \\
\hline Missing & 0.85 (0.59 to 1.23$)$ & - & - & $0.75(0.39$ to 1.5$)$ & 0.40 \\
\hline \multicolumn{6}{|c|}{ First procalcitonin $(\mathrm{ng} / \mathrm{mL} ; \mathrm{SI} \mu \mathrm{g} / \mathrm{L})$ : } \\
\hline $0-0.5$ & Reference & - & - & Reference & - \\
\hline$>0.5$ & 3.24 (2.66 to 3.94$)$ & - & - & $1.54(1.18$ to 2.0$)$ & 0.001 \\
\hline Missing & 0.60 (0.42 to 0.86$)$ & - & - & 0.75 (0.44 to 1.3$)$ & 0.29 \\
\hline \multicolumn{6}{|c|}{ First troponin $(\mathrm{ng} / \mathrm{mL} ; \mathrm{SI} \mu \mathrm{g} / \mathrm{L})$ : } \\
\hline$<0.1$ & Reference & - & - & Reference & - \\
\hline $0.1-1$ & 4.16 (3.22 to 5.38$)$ & - & - & 2.09 (1.51 to 2.9 ) & $<0.001$ \\
\hline$>1$ & $7.53(3.84$ to 14.76$)$ & - & - & 4.78 (2.10 to 10.9$)$ & $<0.001$ \\
\hline Missing & $0.52(0.37$ to 0.73$)$ & - & - & $0.84(0.51$ to 1.4$)$ & 0.49 \\
\hline
\end{tabular}

hospital admission and risk of critical illness among all patients with covid-19, with less influence of chronic pulmonary disease (asthma or chronic obstructive pulmonary disease) and other forms of heart disease. By contrast, we found comorbidities to be less strongly associated with critical illness in patients admitted to hospital. Among those patients, we noted the importance of hypoxia despite the provision of supplemental oxygen and early increases in inflammatory markers (especially D-dimer and C reactive protein) in distinguishing between patients who go on to develop critical illness and those who do not. In the population admitted to hospital, measures of inflammation were much more important than personal characteristics and comorbidities.

\section{Comparison with other studies}

The first detailed covid-19 case series included 1099 hospital inpatients with laboratory confirmed infection in China, of whom only 25 (2.3\%) underwent invasive ventilation and 15 (1.4\%) died. ${ }^{1}$ A recent report of 5700 patients admitted to hospital from a different health system in New York City found that at least 9.7\% had already died $(24.5 \%$ of mechanically ventilated patients); however, $53.8 \%$ of the patients in this study (72.2\% of ventilated) were still in hospital, with a median follow-up of only 4.5 days. By contrast, $23.6 \%$ of patients admitted to hospital in our case series required invasive ventilation and $24.3 \%$ have died as of 5 May, with $94 \%$ of patients having completed hospital admissions. If all remaining inpatients died, the overall mortality would be a maximum of $30.5 \%$. Given the high prevalence of disease in New York City and the relative paucity of baseline hospital beds per capita (1.5-2.7 beds per 1000 in all boroughs except Manhattan), admission thresholds might be higher in New York City than in China (4.2 beds per 1000). ${ }^{25} 26$ Moreover, in the series from China, only a quarter of 


\begin{tabular}{|c|c|c|c|c|}
\hline \multirow[b]{2}{*}{ Characteristics } & \multicolumn{2}{|c|}{$\begin{array}{l}\text { Excluding vital signs and laboratory results } \\
(\mathrm{n}=2737)\end{array}$} & \multicolumn{2}{|c|}{$\begin{array}{l}\text { Including vital signs and laboratory results } \\
(\mathrm{n}=2737)\end{array}$} \\
\hline & Hazard ratio $(95 \% \mathrm{Cl})$ & P value & Hazard ratio $(95 \% \mathrm{Cl})$ & $P$ value \\
\hline \multicolumn{5}{|l|}{ Week: } \\
\hline 10-11 (March 2 to 15$)$ & Reference & - & Reference & - \\
\hline 12 (March 16 to 22 ) & 0.87 (0.54 to 1.41$)$ & 0.58 & 1.07 (0.62 to 1.84$)$ & 0.80 \\
\hline 13 (March 23 to 29) & $0.84(0.53$ to 1.32$)$ & 0.44 & $0.96(0.55$ to 1.68$)$ & 0.88 \\
\hline 14 (March 30 to April 5) & $0.82(0.52$ to 1.30$)$ & 0.40 & 0.85 (0.49 to 1.50$)$ & 0.58 \\
\hline 15 (April 6 to April 8) & $0.73(0.44$ to 1.19$)$ & 0.21 & 0.67 (0.37 to 1.22$)$ & 0.19 \\
\hline \multicolumn{5}{|l|}{ Age (years): } \\
\hline 19-44 & Reference & - & Reference & - \\
\hline $45-54$ & $2.59(1.56$ to 4.32$)$ & $<0.001$ & 1.95 (1.16 to 3.31$)$ & 0.01 \\
\hline $55-64$ & $4.40(2.73$ to 7.11$)$ & $<0.001$ & $3.18(1.93$ to 5.21$)$ & $<0.001$ \\
\hline $65-74$ & 6.99 (4.34 to 11.27$)$ & $<0.001$ & $4.83(2.93$ to 7.96$)$ & $<0.001$ \\
\hline$\geq 75$ & $10.34(6.37$ to 16.79$)$ & $<0.001$ & $7.69(4.60$ to 12.84$)$ & $<0.001$ \\
\hline Men & 1.27 (1.08 to 1.50$)$ & 0.005 & $0.92(0.77$ to 1.11$)$ & 0.39 \\
\hline \multicolumn{5}{|l|}{ Race/ethnicity: } \\
\hline Non-Hispanic white & Reference & - & Reference & - \\
\hline Non-Hispanic African-American & $0.78(0.60$ to 1.02$)$ & 0.07 & $0.71(0.53$ to 0.94$)$ & 0.02 \\
\hline Asian & $1.29(0.94$ to 1.77$)$ & 0.12 & $1.26(0.91$ to 1.75$)$ & 0.16 \\
\hline Hispanic & 1.17 (0.95 to 1.44$)$ & 0.13 & 1.21 (0.98 to 1.49$)$ & 0.07 \\
\hline Other/multiracial & 1.07 (0.80 to 1.45$)$ & 0.64 & 1.17 (0.86 to 1.60$)$ & 0.31 \\
\hline Unknown & 1.09 (0.71 to 1.67$)$ & 0.69 & $1.23(0.82$ to 1.83$)$ & 0.32 \\
\hline \multicolumn{5}{|l|}{ Smoking status: } \\
\hline Never & Reference & - & Reference & - \\
\hline Former & $1.13(0.93$ to 1.37$)$ & 0.21 & 1.07 (0.88 to 1.31$)$ & 0.49 \\
\hline Current & $0.90(0.61$ to 1.31$)$ & 0.57 & $0.92(0.62$ to 1.38$)$ & 0.69 \\
\hline Unknown & $1.56(1.26$ to 1.93$)$ & $<0.001$ & $1.50(1.21$ to 1.86$)$ & $<0.001$ \\
\hline \multicolumn{5}{|l|}{ BMI: } \\
\hline$<25$ & Reference & - & Reference & - \\
\hline $25.0-29.9$ & 0.91 (0.74 to 1.11$)$ & 0.34 & $1.01(0.82$ to 1.25$)$ & 0.94 \\
\hline $30.0-39.9$ & $1.02(0.82$ to 1.27$)$ & 0.85 & $1.08(0.87$ to 1.36$)$ & 0.48 \\
\hline$\geq 40$ & $1.41(0.98$ to 2.01$)$ & 0.06 & $1.45(0.99$ to 2.13$)$ & 0.05 \\
\hline Unknown & 1.85 (1.13 to 3.02$)$ & 0.01 & $1.97(1.23$ to 3.17$)$ & 0.005 \\
\hline Coronary artery disease & $1.12(0.92$ to 1.36$)$ & 0.24 & $1.10(0.90$ to 1.35$)$ & 0.36 \\
\hline Heart failure & $1.77(1.43$ to 2.20$)$ & $<0.001$ & 1.54 (1.23 to 1.93$)$ & $<0.001$ \\
\hline Hyperlipidemia & $0.95(0.79$ to 1.13$)$ & 0.55 & $0.98(0.82$ to 1.17$)$ & 0.79 \\
\hline Hypertension & $0.94(0.76$ to 1.16$)$ & 0.54 & $0.98(0.78$ to 1.23$)$ & 0.86 \\
\hline Diabetes & $1.10(0.93$ to 1.31$)$ & 0.26 & $1.01(0.85$ to 1.21$)$ & 0.87 \\
\hline $\begin{array}{l}\text { Asthma or chronic obstructive } \\
\text { pulmonary disease }\end{array}$ & $0.93(0.76$ to 1.15$)$ & 0.51 & 1.03 (0.83 to 1.29$)$ & 0.76 \\
\hline Chronic kidney disease & $1.18(0.97$ to 1.43$)$ & 0.10 & $0.92(0.73$ to 1.16$)$ & 0.49 \\
\hline Cancer & $1.31(1.05$ to 1.62$)$ & 0.02 & $1.29(1.03$ to 1.62$)$ & 0.03 \\
\hline \multicolumn{5}{|l|}{ Temperature on presentation $\left({ }^{\circ} \mathrm{C}\right)$ : } \\
\hline$<38$ & - & - & Reference & - \\
\hline 38 to 39 & - & - & $1.17(0.96$ to 1.43$)$ & 0.11 \\
\hline$>39$ & - & - & $1.04(0.79$ to 1.37$)$ & 0.79 \\
\hline \multicolumn{5}{|l|}{$\begin{array}{l}\text { Oxygen saturation on presentation } \\
(\%) \text { : }\end{array}$} \\
\hline$>92$ & - & - & Reference & - \\
\hline $88-92$ & - & - & $1.46(1.18$ to 1.79$)$ & $<0.001$ \\
\hline$<88$ & - & - & $2.00(1.61$ to 2.48$)$ & $<0.001$ \\
\hline Missing & - & - & $1.03(0.62$ to 1.71$)$ & 0.92 \\
\hline \multicolumn{5}{|l|}{$\begin{array}{l}\text { First lymphocyte count }\left(10^{3} / \mu \mathrm{L} ; \mathrm{SI}\right. \\
\left.10^{9} / \mathrm{L}\right) \text { : }\end{array}$} \\
\hline$>1.2$ & - & - & Reference & - \\
\hline$>0.8-1.2$ & - & - & $0.89(0.70$ to 1.14$)$ & 0.37 \\
\hline $0.5-0.8$ & - & - & $1.04(0.84$ to 1.28$)$ & 0.72 \\
\hline$<0.5$ & - & - & $1.38(1.05$ to 1.81$)$ & 0.02 \\
\hline Missing & - & - & $2.16(1.09$ to 4.27$)$ & 0.03 \\
\hline \multicolumn{5}{|l|}{ First creatinine $(\mathrm{mg} / \mathrm{dL})^{\star}$ : } \\
\hline $0-1.1$ & - & - & Reference & - \\
\hline$>1.1-2$ & - & - & $1.36(1.11$ to 1.68$)$ & 0.003 \\
\hline$>2$ & - & - & $1.49(1.08$ to 2.04$)$ & 0.01 \\
\hline Missing & - & - & $1.48(0.56$ to 3.90$)$ & 0.43 \\
\hline
\end{tabular}




\begin{tabular}{|c|c|c|c|c|}
\hline \multirow[b]{2}{*}{ Characteristics } & \multicolumn{2}{|c|}{$\begin{array}{l}\text { Excluding vital signs and laboratory results } \\
(\mathrm{n}=2737)\end{array}$} & \multicolumn{2}{|c|}{$\begin{array}{l}\text { Including vital signs and laboratory results } \\
(\mathrm{n}=2737)\end{array}$} \\
\hline & Hazard ratio $(95 \% \mathrm{Cl})$ & $P$ value & Hazard ratio $(95 \% \mathrm{Cl})$ & $P$ value \\
\hline \multicolumn{5}{|c|}{ First $\mathrm{C}$ reactive protein $(\mathrm{mg} / \mathrm{L})+$ : } \\
\hline $0-15$ & - & - & Reference & - \\
\hline$>15-100$ & - & - & $3.52(1.72$ to 7.18$)$ & $<0.001$ \\
\hline$>100-200$ & - & - & $4.66(2.25$ to 9.62$)$ & $<0.001$ \\
\hline$>200$ & - & - & 5.07 (2.41 to 10.67$)$ & $<0.001$ \\
\hline Missing & - & - & $3.46(1.38$ to 8.64$)$ & 0.008 \\
\hline \multicolumn{5}{|c|}{ First D-dimer (ng/mL; SI $\mu \mathrm{g} / \mathrm{L})$ : } \\
\hline $0-250$ & - & - & Reference & \\
\hline$>250-500$ & - & - & 1.50 (1.14 to 1.98$)$ & 0.004 \\
\hline$>500-1000$ & - & - & $1.70(1.26$ to 2.28$)$ & $<0.001$ \\
\hline$>1000-2500$ & - & - & $1.67(1.18$ to 2.36$)$ & 0.004 \\
\hline$>2500$ & - & - & $2.16(1.57$ to 2.98$)$ & $<0.001$ \\
\hline Missing & - & - & $1.59(1.04$ to 2.44$)$ & 0.03 \\
\hline \multicolumn{5}{|c|}{ First ferritin (ng/mL; SI $\mu \mathrm{g} / \mathrm{L})$ : } \\
\hline $0-300$ & - & - & Reference & - \\
\hline$>300-500$ & - & - & $1.08(0.78$ to 1.49$)$ & 0.65 \\
\hline$>500-1000$ & - & - & $1.19(0.90$ to 1.57$)$ & 0.23 \\
\hline$>1000-2500$ & - & - & $1.22(0.92$ to 1.61$)$ & 0.18 \\
\hline$>2500$ & - & - & $1.36(0.97$ to 1.90$)$ & 0.08 \\
\hline Missing & - & - & $1.88(1.02$ to 3.48$)$ & 0.04 \\
\hline \multicolumn{5}{|c|}{ First procalcitonin $(\mathrm{ng} / \mathrm{mL}$; SI $\mu \mathrm{g} / \mathrm{L})$ : } \\
\hline $0-0.5$ & - & - & Reference & - \\
\hline$>0.5$ & - & - & $1.58(1.28$ to 1.95$)$ & $<0.001$ \\
\hline Missing & - & - & 0.95 (0.59 to 1.52$)$ & 0.82 \\
\hline \multicolumn{5}{|c|}{ First troponin $(\mathrm{ng} / \mathrm{mL} ; \mathrm{SI} \mu \mathrm{g} / \mathrm{L})$ : } \\
\hline$<0.1$ & - & - & Reference & - \\
\hline $0.1-1$ & - & - & $1.48(1.19$ to 1.84$)$ & $<0.001$ \\
\hline$>1$ & - & - & $2.12(1.39$ to 3.22$)$ & $<0.001$ \\
\hline Missing & - & - & $0.58(0.32$ to 1.06$)$ & 0.08 \\
\hline
\end{tabular}

the patients had any chronic comorbidity, whereas in our series $80 \%$ of patients admitted to hospital had at least one of eight major chronic diseases. ${ }^{1}$

In fact, outcomes in most of the reports were similar to ours. A commentary by the Chinese Center for Disease Control and Prevention described outcomes for 72314 patients, of whom $14 \%$ had severe disease (similar to patients admitted to hospital in our series) and 5\% had critical illness with respiratory or multi-organ failure (similar to those requiring intensive care unit (ICU) level care or mechanical ventilation in our series). ${ }^{2}$ Among patients with critical illness, mortality was 49\%; we found this to be $57 \%$ among all ICU or ventilated patients. Finally, our results are also consistent with a recent national case series reported by the US Centers for Disease Control and Prevention, which found that 457 of 1037 (44.1\%) patients admitted to hospital required ICU admission, and that three quarters had at least one chronic condition. ${ }^{6}$ Overall, the death rate we find for critically ill patients is a bit higher than the typical mortality rate from acute respiratory distress syndrome (ARDS) of about 35-45\%. ${ }^{27} 28$

The comorbidities we identified as associated with hospital admission in covid-19 are largely similar to those associated with any type of severe infectious disease requiring hospital admission or ICU level care, ${ }^{29}$ though we were surprised that chronic pulmonary disease did not feature more prominently. Others have also noted the absence of asthma and chronic obstructive pulmonary disease as risks for severity of illness in patients with covid-19. ${ }^{30}$ The epidemiologic and/or pathophysiologic reasons for this are unknown. The demographic distribution of patients admitted to hospital with covid-19 is also similar to those admitted with other acute respiratory infections. For instance, though advanced age was by far the most important predictor of hospital admission and severe outcomes (as it is for most illnesses), 53\% of patients admitted to hospital were younger than 65 years. This is typical of the pattern for hospital admissions in viral respiratory disease. Studies of patients admitted to hospital with influenza in the United States have found that people younger than 65 years (including children) account for $53-57 \%$ of influenza related hospital admissions. ${ }^{31} 32$

Surprisingly, though some have speculated that high rates of smoking in China explained some of the morbidity in those patients, we did not find tobacco use to be associated with increased risk of hospital admission or of critical illness; in fact, it even seemed protective for hospital admission. However, this could be artifactual: patients with unknown smoking status had significantly higher risks of admission and of critical illness. It is possible that data are disproportionately missing for current or former smokers who might not care to answer that question; if so, that would attenuate the apparent benefit of smoking. Few $(<5 \%)$ patients had a recorded history of vaping; separate analyses could not be conducted for this group. 

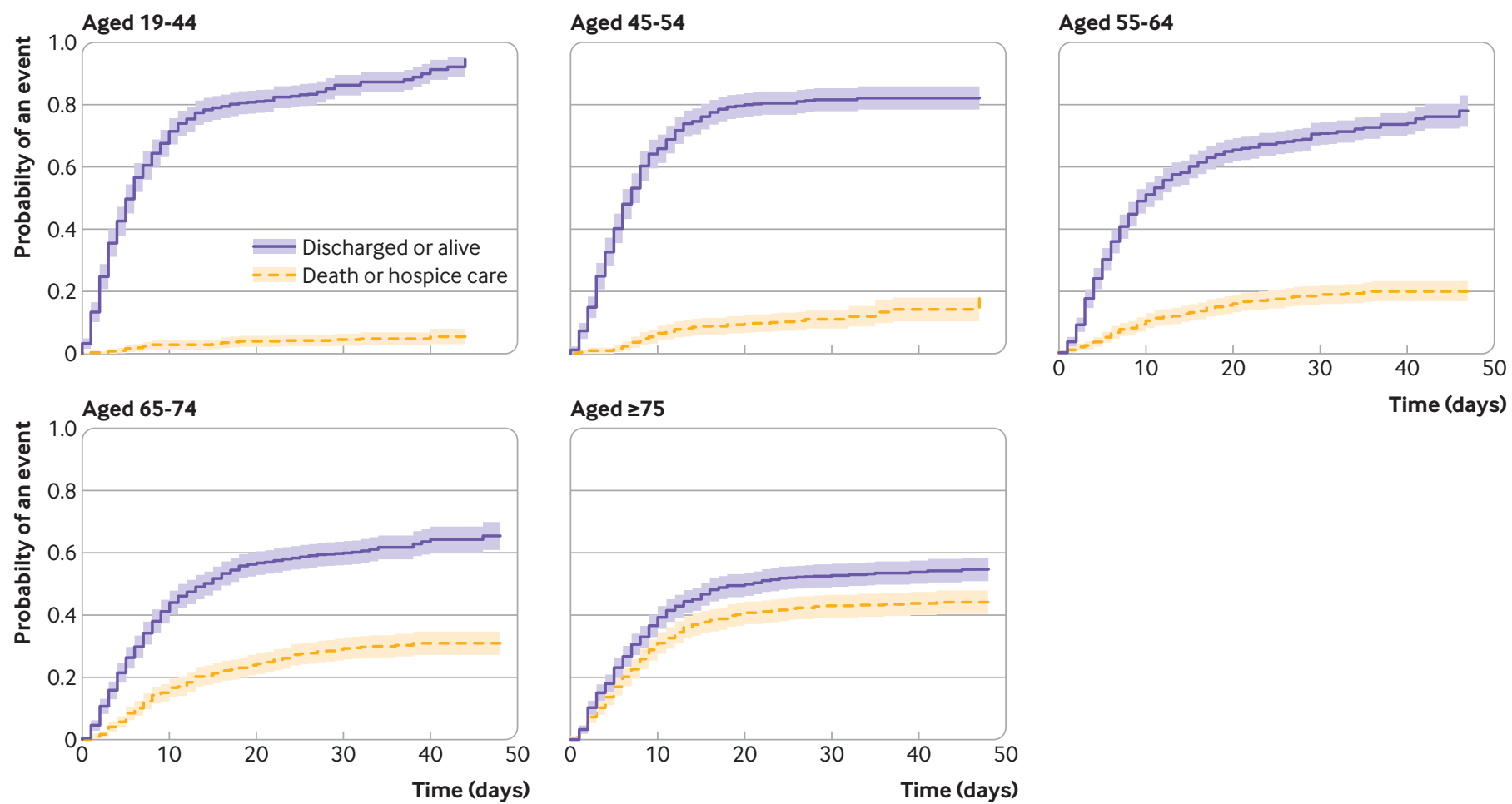

Fig 2 | Cumulative incidence function for discharge alive or death, by age group. Shading represents $95 \%$ confidence intervals

We noted a striking association of inflammatory markers with mortality and critical illness among patients admitted to hospital; particularly, early increases in $\mathrm{C}$ reactive protein and D-dimer levels.

Heart failure diagnosis
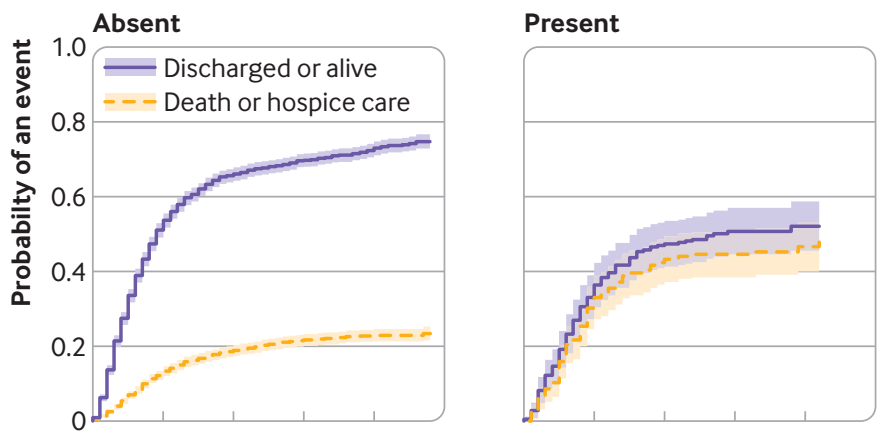

Diabetes diagnosis
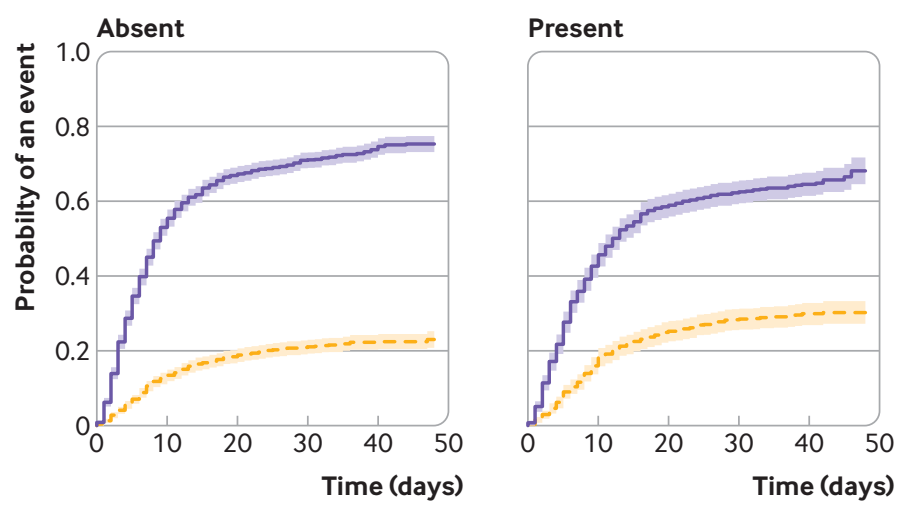

Hyperinflammatory states are well described in severe sepsis $^{33}$; however, the degree to which covid-19 related inflammation is similar to or different from that typically found in sepsis is unknown. Some

Cancer diagnosis
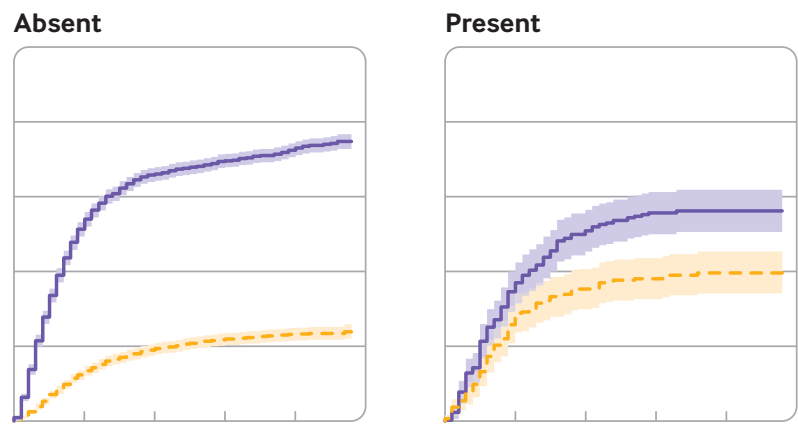

Sex

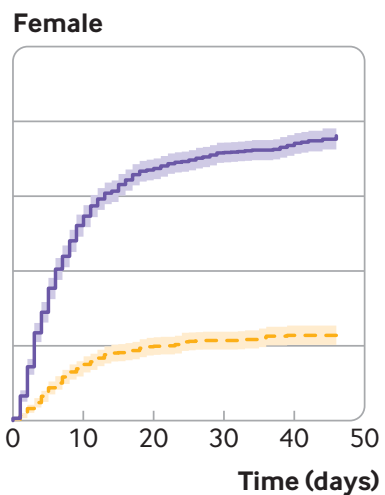

Fig 3 | Cumulative incidence function for discharge alive or death, by heart failure, cancer, diabetes, and sex. Shading represents $95 \%$ confidence intervals 


\section{Oxygen saturation at presentation}

93-100

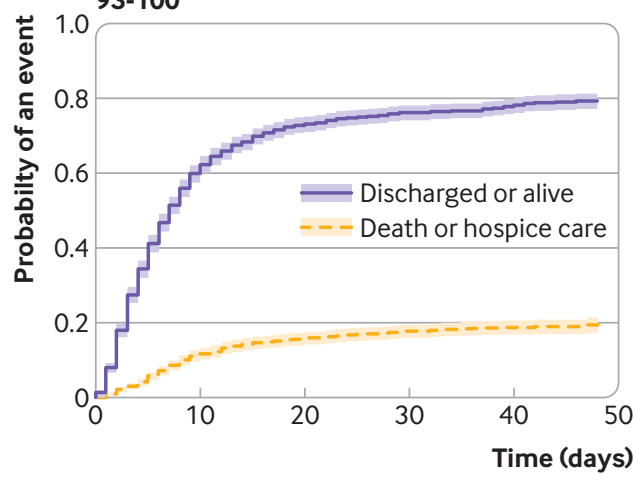

First D-dimer (ng/mL)

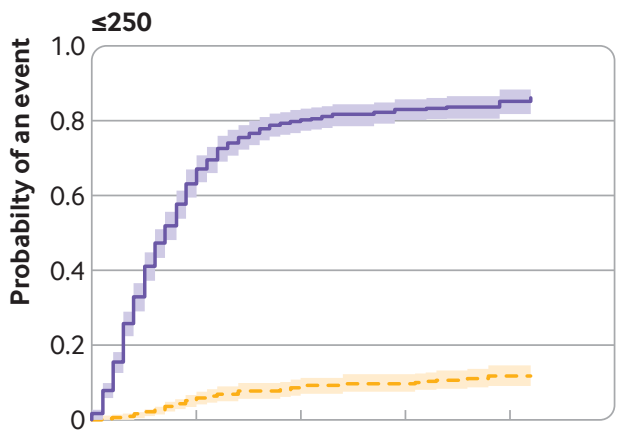

1001-2500

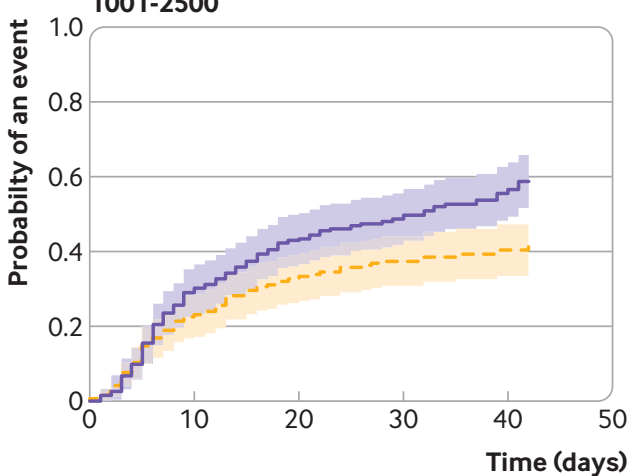

89-92

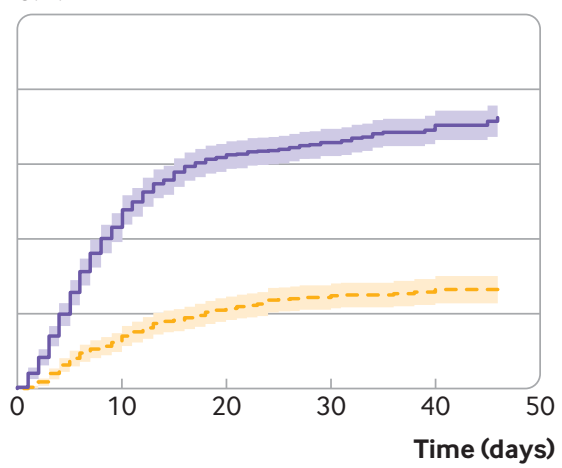

251-500

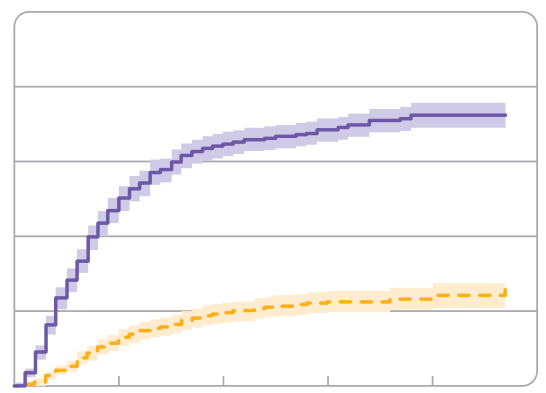

$>2500$

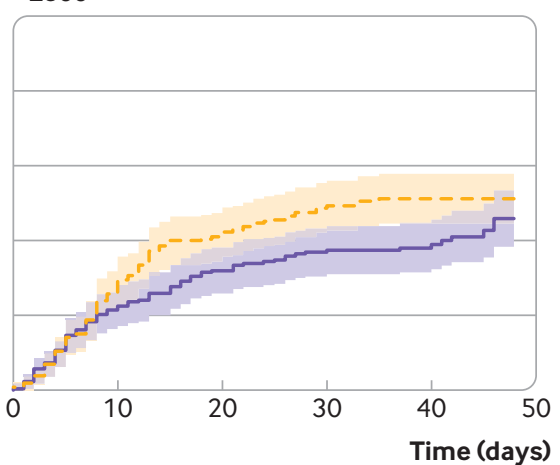

$<88$

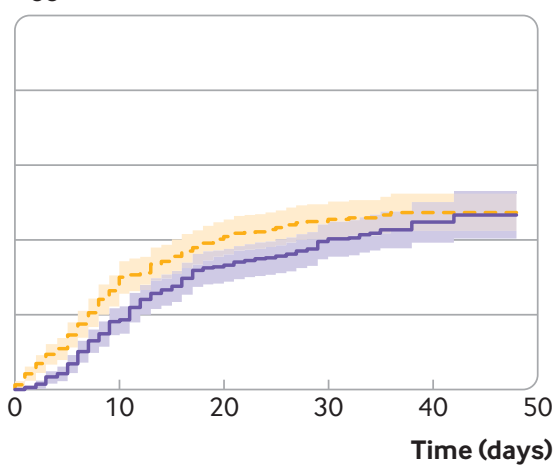

501-1000

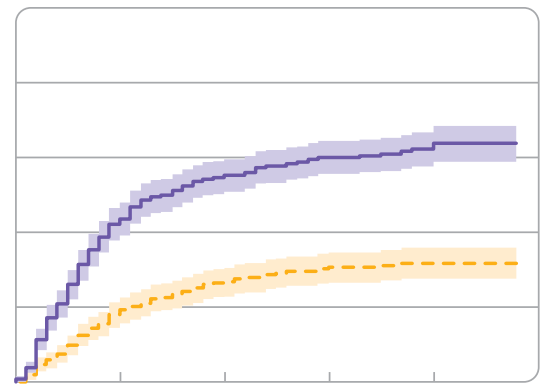

Missing

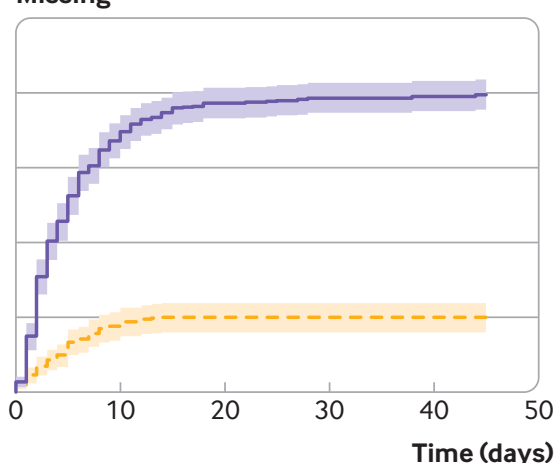

Fig 4 | Cumulative incidence function for discharge alive or death, by admission oxygenation and D-dimer levels. Shading represents $95 \%$ confidence intervals

emerging case reports suggest that patients with severe covid-19 disease are developing complications from hypercoagulability, ${ }^{10}$ including both pulmonary emboli $^{34}$ and microscopic thrombi. ${ }^{35}$ It is notable that one of the chronic conditions strongly associated with critical illness was obesity. Obesity is well recognized to be a pro-inflammatory condition. ${ }^{36}{ }^{37}$ In addition, this might explain why hyperlipidemia seemed protective for hospital admission in multivariable analysis, though not in univariate analysis and not for critical illness: statin treatment is anti-inflammatory and has been shown to reduce cytokine levels. ${ }^{38}$ Some studies suggest that an increased low density lipoprotein cholesterol level itself might be beneficial in reducing mortality from respiratory diseases through direct anti-infectious properties, though mean low density lipoprotein cholesterol levels were low in our population. Finally, we noted that early increases in procalcitonin levels were strongly associated with critical illness and mortality, although covid-19 appears to be characterized by low procalcitonin levels in general. Though many patients with increased procalcitonin levels and critical illness were treated with antibiotics, it remains unclear whether these patients actually had bacterial disease or whether the increase in procalcitonin levels was another manifestation of a general hyperinflammatory state.

Last, we were interested to note that, while risk of hospital admission was constant across the study period, risk of critical illness (and directionally, but not significantly, mortality) decreased over time. Our institution was stretched but not overwhelmed by the epidemic and did not experience important equipment or treatment shortages. The improvement in outcomes 


\section{First $\mathrm{C}$ reactive protein $(\mathrm{mg} / \mathrm{L})$}

$\leq 15$
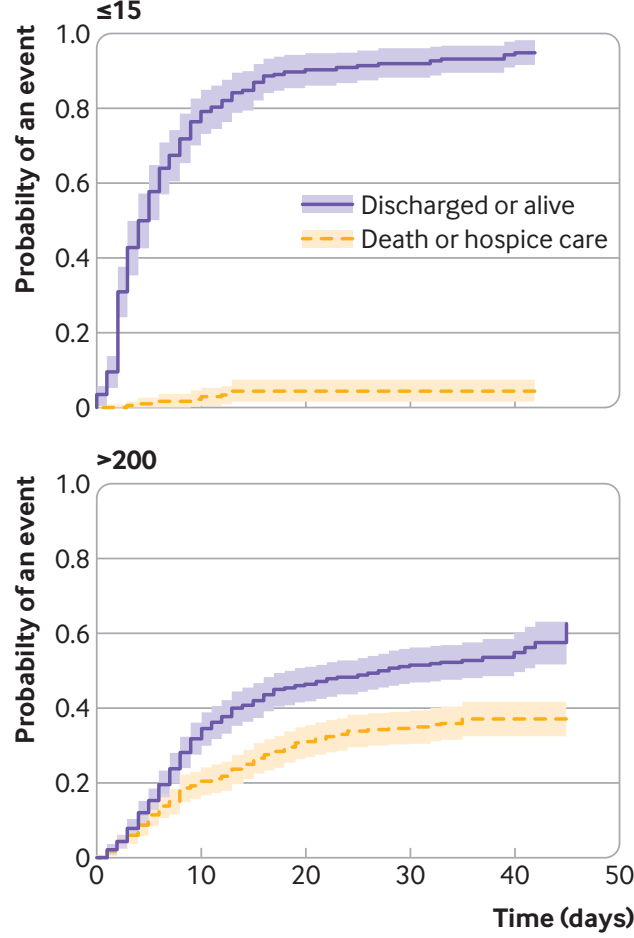

First lymphocyte count $\left(10^{3} / \mu \mathrm{L}\right)$
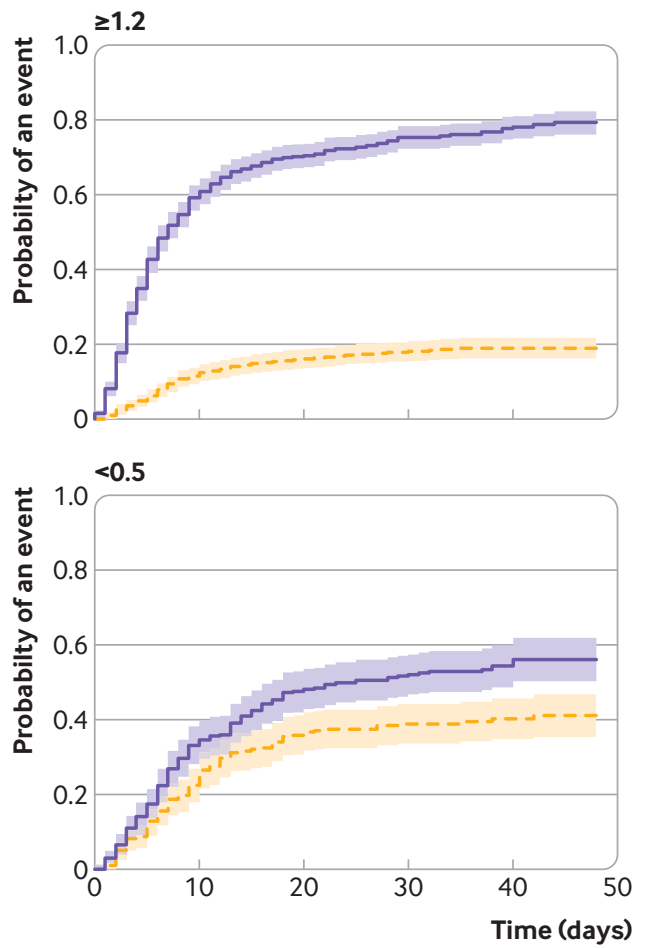

$>15-100$

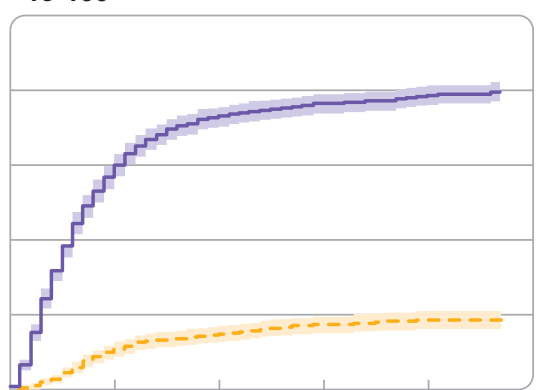

Missing

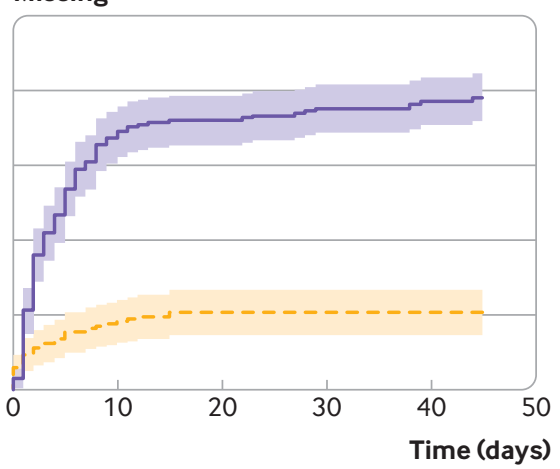

$0.85-<1.2$

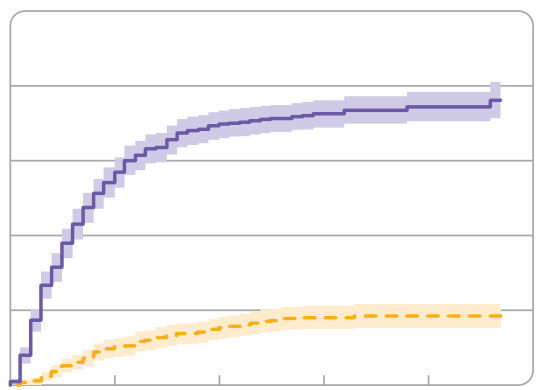

Missing

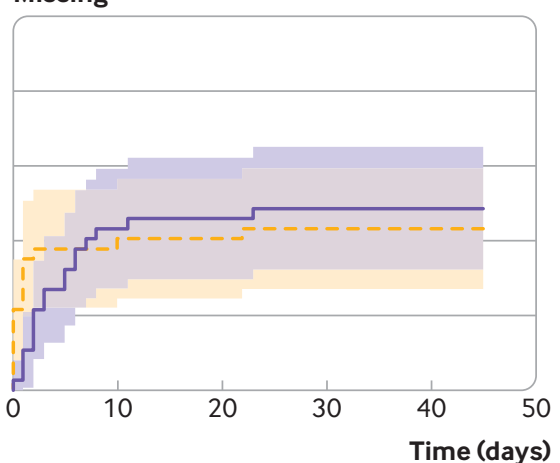

$>100-200$

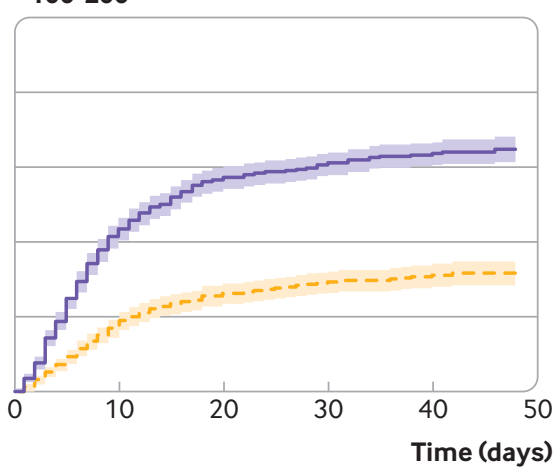

$0.5-<0.85$

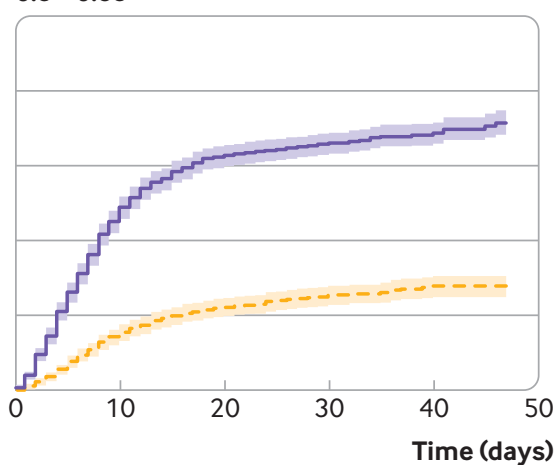

Fig 5 | Cumulative incidence function for discharge alive or death, by C reactive protein and lymphocyte count. Shading represents $95 \%$ confidence intervals

over time (in the setting of a functioning health system) raises the possibility that familiarity with the disease, ongoing iteration of protocols and practices in response to observed outcomes, and initiation of new treatments might improve outcomes even in the absence of vaccination or regimens known to be effective.

\section{Limitations of this study}

This study has several limitations. Most important, data on patients who were not admitted to hospital were more limited because many did not have vital signs or blood samples collected and might not have had as detailed a medical history taken. They 
are also a heterogeneous group, made even more heterogeneous by changing testing thresholds over time. We might therefore have overestimated the importance of chronic disease in risk of hospital admission. This limitation could be further exacerbated by the fact that patients treated and discharged from the emergency department were not commonly tested and thus omitted from our analysis unless later admitted to hospital, yet they might be more likely to have comorbidities than those tested in outpatient settings. However, a sensitivity analysis including these patients showed similar results. Our patients were all from a single geographic region, treated within a single health system; factors associated with poor outcomes might differ elsewhere, though our patient population is diverse. We did not have data on inflammatory markers available for patients not admitted to hospital; it is possible that these would have been associated with risk of hospital admission, not just critical illness, if available. Moreover, a standardized admission laboratory protocol was only established about two weeks into the epidemic, resulting in missing laboratory data for earlier patients, especially those who were less acutely ill. Finally, our outcome assignments might be imperfect: some patients in the group who were not admitted to hospital might have been admitted to other institutions, and some discharged patients might have been readmitted elsewhere with critical illness or could have died post-discharge.

\section{Conclusion}

Overall, we found that age and comorbidities are powerful predictors of requirement for admission to hospital rather than outpatient care; however, degree of oxygen impairment and markers of inflammation are most strongly associated with poor outcomes during hospital admission. Clinicians should consider routinely obtaining inflammatory markers during hospital stay for people with covid-19.

We thank Andrew Admon, Brian Bosworth, Steven Chatfield, Thomas Doonan, Robert Grossman, Juan Peralta, and Daniel Widawsky for operational and technical support; the thousands of NYU Langone Health employees who have cared for these patients; and the reviewers who improved the paper.

Contributors: CMP, LO'D, KAT, RJC, FF, and LIH conceived the project. CMP, YC, HR, and LIH obtained, validated, and cleaned the data. JY and SAJ performed the statistical analyses. RJC and FF provided administrative and operational support. LIH supervised the project and drafted the manuscript. All authors discussed the results and contributed to the final manuscript. LIH acts as guarantor. The corresponding author attests that all listed authors meet authorship criteria and that no others meeting the criteria have been omitted.

Funding: This work was funded in part by the Kenneth C Griffin Charitable Fund, which had no role in the study design; the collection, analysis, and interpretation of data; the writing of the report; or the decision to submit the article for publication.

Competing interests: All authors have completed the ICMJE uniform disclosure form at www.icmje.org/coi disclosure.pdf and declare: support from the Kenneth C Griffin Charitable Fund for submitted work; no financial relationships with any organizations that might have an interest in the submitted work in the previous three years; no other relationships or activities that could appear to have influenced the submitted work.
Ethical approval: This study was approved by the NYU Grossman School of Medicine Institutional Review Board (No i20-00485), which granted both a waiver of informed consent and a waiver of the Health Information Portability and Privacy Act.

Data sharing: Identifiable patient level data from this project are not available to the public

Dissemination to participants and related patient and public communities: A preprint version of the study is publicly available on medRxiv at https://doi.org/10.1101/2020.04.08.20057794. Lay summaries of the article will be posted on Twitter and will be discussed with journalists as the opportunity arises.

The corresponding author $(\mathrm{LIH})$ affirms that the manuscript is an honest, accurate, and transparent account of the study being reported; that no important aspects of the study have been omitted; and that any discrepancies from the study as planned have been explained.

This is an Open Access article distributed in accordance with the Creative Commons Attribution Non Commercial (CC BY-NC 4.0) license, which permits others to distribute, remix, adapt, build upon this work non-commercially, and license their derivative works on different terms, provided the original work is properly cited and the use is noncommercial. See: http://creativecommons.org/licenses/by-nc/4.0/.

1 Guan WJ, Ni ZY, Hu Y, et al, China Medical Treatment Expert Group for Covid-19. Clinical characteristics of coronavirus disease 2019 in China. N Engl / Med 2020;382:1708-20. doi:10.1056/NEJMoa2002032

2 Wu Z, McGoogan JM. Characteristics of and important lessons from the coronavirus disease 2019 (covid-19) outbreak in China: summary of a report of 72314 cases from the Chinese Center for Disease Control and Prevention. JAMA 2020. doi:10.1001/jama.2020.2648

3 Livingston E, Bucher K. Coronavirus disease 2019 (covid-19) in Italy. JAMA 2020. doi:10.1001/jama.2020.4344

4 Onder G, Rezza G, Brusaferro S. Case-fatality rate and characteristics of patients dying in relation to covid-19 in Italy. JAMA 2020 doi:10.1001/jama.2020.4683

5 CDC COVID-19 Response Team. Severe outcomes among patients with coronavirus disease 2019 (covid-19) - United States, February 12-March 16, 2020. MMWR Morb Mortal Wkly Rep 2020;69:343-6. doi:10.15585/mmwr.mm6912e2

6 CDC COVID-19 Response Team. Preliminary estimates of the prevalence of selected underlying health conditions among patients with coronavirus disease 2019 - United States, February 12-March 28, 2020. MMWR Morb Mortal Wkly Rep 2020;69:382-6. doi:10.15585/mmwr.mm6913e2

7 Richardson S, Hirsch JS, Narasimhan M, et al, and the Northwell COVID-19 Research Consortium. Presenting characteristics, comorbidities, and outcomes among 5700 patients hospitalized with covid-19 in the New York City area. JAMA 2020. doi:10.1001/ jama.2020.6775

8 Wu C, Chen X, Cai Y, et al. Risk factors associated with acute respiratory distress syndrome and death in patients with coronavirus disease 2019 pneumonia in Wuhan, China. JAMA Intern Med 2020. doi:10.1001/jamainternmed.2020.0994

9 Wang Z, Yang B, Li Q, Wen L, Zhang R. Clinical features of 69 cases with coronavirus disease 2019 in Wuhan, China. Clin Infect Dis 2020:ciaa272. doi:10.1093/cid/ciaa272

10 Zhou F, Yu T, Du R, et al. Clinical course and risk factors for mortality of adult inpatients with covid-19 in Wuhan, China: a retrospective cohort study. Lancet 2020;395:1054-62. doi:10.1016/S01406736(20)30566-3

11 Guo T, Fan Y, Chen M, et al. Cardiovascular implications of fatal outcomes of patients with coronavirus disease 2019 (covid-19). IAMA Cardiol 2020. doi:10.1001/jamacardio.2020.1017

12 Wang D, Hu B, Hu C, et al. Clinical characteristics of 138 hospitalized patients with 2019 novel coronavirus-infected pneumonia in Wuhan, China. JAMA 2020 doi:10.1001/jama.2020.1585

13 Korean Society of Infectious Diseases and Korea Centers for Disease Control and Prevention. Analysis on 54 mortality cases of coronavirus disease 2019 in the Republic of Korea from January 19 to March 10, 2020. J Korean Med Sci 2020;35:e132. doi:10.3346/jkms.2020.35. e132

14 Bhatraju PK, Ghassemieh BJ, Nichols M, et al. Covid-19 in critically ill patients in the Seattle Region - case series. N Engl I Med 2020. doi:10.1056/NEJMoa2004500

15 Grasselli G, Zangrillo A, Zanella A, et al, COVID-19 Lombardy ICU Network. Baseline characteristics and outcomes of 1591 patients infected with SARS-CoV-2 admitted to ICUs of the Lombardy region, Italy. JAMA 2020. doi:10.1001/jama.2020.5394

16 NYC Health. Cases, hospitalizations and deaths. 2020. https://www1. nyc.gov/site/doh/covid/covid-19-data.page\#download.

17 Popescu I, Fingar KR, Cutler E, Guo J, Jiang HJ. Comparison of 3 Safety-Net Hospital Definitions and Association With Hospital Characteristics. JAMA Netw Open 2019;2:e198577. 
18 Fox J, Monette G. Generalized collinearity diagnostics. J Am Stat Assoc 1992;87:178-83. doi:10.1080/01621459.1992.10475190

19 Imdad MU, Aslam M. mctest: multicollinearity diagnostic measures version 1.2.5 2018. https://CRAN.R-project.org/package=mctest.

20 Venables WN, Ripley BD. Modern Applied Statistics. 4th ed. Springer, 2002. doi:10.1007/978-0-387-21706-2

21 Venzon DJ, Moolgavkar SH. A method for computing profilelikelihood based confidence intervals. Appl Stat 1988;37:87-94. doi:10.2307/2347496

22 Fine JP, Grey RJ. A proportional hazards model for the subdistribution of a competing risk. J Am Stat Assoc 1999;94:496-509. doi:10.1080 101621459.1999.10474144

23 Grey RJ. A class of K-sample tests for comparing the cumulative incidence of a competing risk. Ann Stat 2019;16:1141-54. doi:10.1214/aos/1176350951

24 Sfumato P. Goodness-of-fit for time-to-event data. 2020. https:// www.rdocumentation.org/packages/goftte/versions/1.0.5.

25 Melby C, Gu J, Rojanasakul M. Mapping New York City hospital beds as coronavirus cases surge. 2020 https://www.bloomberg.com/ graphics/2020-new-york-coronavirus-outbreak-how-many-hospitalbeds/.

26 World Health Organization. Hospital beds (per 10000 population). 2020 https://www.who.int/data/gho/data/indicators/indicatordetails/GHO/hospital-beds-(per-10-000-population).

27 Rubenfeld GD, Caldwell E, Peabody E, et al. Incidence and outcomes of acute lung injury. N Engl / Med 2005;353:1685-93. doi:10.1056/ NEJMoa050333

28 Bellani G, Laffey JG, Pham T, et al, LUNG SAFE Investigators, ESICM Trials Group. Epidemiology, patterns of care, and mortality for patients with acute respiratory distress syndrome in intensive care units in 50 countries. JAMA 2016;315:788-800. doi:10.1001/ jama.2016.0291

29 Cecconi M, Evans L, Levy M, Rhodes A. Sepsis and septic shock[published Online First: 2018/06/26]. Lancet 2018;392:7587. doi:10.1016/S0140-6736(18)30696-2
30 Halpin DMG, Faner R, Sibila O, Badia JR, Agusti A. Do chronic respiratory diseases or their treatment affect the risk of SARS-CoV-2 infection?Lancet Respir Med 2020;8:436-8. doi:10.1016/S22132600(20)30167-3

31 Simonsen L, Fukuda K, Schonberger LB, Cox NJ. The impact of influenza epidemics on hospitalizations. / Infect Dis 2000;181:831 7. doi:10.1086/315320

32 Zhou H, Thompson WW, Viboud CG, et al. Hospitalizations associated with influenza and respiratory syncytial virus in the United States, 1993 2008. Clin Infect Dis 2012;54:1427-36. doi:10.1093/cid/cis211

33 Hotchkiss RS, Karl IE. The pathophysiology and treatment of sepsis. N Engl J Med 2003;348:138-50. doi:10.1056/NEJMra021333

34 Danzi GB, Loffi M, Galeazzi G, Gherbesi E. Acute pulmonary embolism and COVID-19 pneumonia: a random association?Eur Heart J 2020:ehaa254. doi:10.1093/eurheartj/ehaa254

35 Magro C, Mulvey JJ, Berlin D, et al. Complement associated microvascular injury and thrombosis in the pathogenesis of severe COVID-19 infection: a report of five cases. Transl Res 2020;S1931 5244(20)30070-0. doi:10.1016/j.trsl.2020.04.007

36 Schmidt FM, Weschenfelder J, Sander C, et al. Inflammatory cytokines in general and central obesity and modulating effects of physical activity. PloS One 2015:10:e0121971. doi:10.1371/journal.pone.0121971

37 Caër C, Rouault C, Le Roy T, et al. Immune cell-derived cytokines contribute to obesity-related inflammation, fibrogenesis and metabolic deregulation in human adipose tissue. Sci Rep 2017:7:3000. doi:10.1038/s41598-017-02660-w

38 Geovanini GR, Libby P. Atherosclerosis and inflammation: overview and updates. Clin Sci (Lond) 2018;132:1243-52. doi:10.1042 CS20180306

39 Jacobs D, Blackburn H, Higgins M, et al. Report of the conference on low blood cholesterol: mortality associations. Circulation 1992:86:1046-60. doi:10.1161/01.CIR.86.3.1046

Web appendix: Supplementary material 